\title{
Two-Dimensional Layered Double Hydroxides for Reactions of Methanation and Methane Reforming in C1 Chemistry
}

\author{
Panpan Li ${ }^{1}$, Feng $\mathrm{Yu}^{1}{ }^{1 *} \mathbb{D}$, Naveed Altaf ${ }^{2}$, Mingyuan $\mathrm{Zhu}{ }^{1}$, Jiangbing $\mathrm{Li}^{1}{ }^{1}, \mathrm{Bin}_{\mathrm{Dai}}{ }^{1}$ \\ and Qiang Wang ${ }^{1,2, *}$ \\ 1 Key Laboratory for Green Processing of Chemical Engineering of Xinjiang Bingtuan, School of Chemistry \\ and Chemical Engineering, Shihezi University, Shihezi 832003, China; ppl_19910109@163.com (P.L.); \\ zhuminyuan@shzu.edu.cn (M.Z.); ljbin@shzu.edu.cn (J.L.); db_tea@shzu.edu.cn (B.D.) \\ 2 Environmental Functional Nanomaterials (EFN) Laboratory, College of Environmental Science and \\ Engineering, Beijing Forestry University, Beijing 100083, China; naveed007@bjfu.edu.cn \\ * Correspondence: yufeng05@mail.ipc.ac.cn (F.Y.); qiangwang@bjfu.edu.cn (Q.W.); \\ Tel.: +86-993-205-7272 (F.Y.); Fax: +86-993-205-7270 (F.Y.)
}

Received: 27 December 2017; Accepted: 28 January 2018; Published: 31 January 2018

\begin{abstract}
CH}_{4}$ as the paramount ingredient of natural gas plays an eminent role in $\mathrm{C} 1$ chemistry. $\mathrm{CH}_{4}$ catalytically converted to syngas is a significant route to transmute methane into high value-added chemicals. Moreover, the $\mathrm{CO} / \mathrm{CO}_{2}$ methanation reaction is one of the potent technologies for $\mathrm{CO}_{2}$ valorization and the coal-derived natural gas production process. Due to the high thermal stability and high extent of dispersion of metallic particles, two-dimensional mixed metal oxides through calcined layered double hydroxides (LDHs) precursors are considered as the suitable supports or catalysts for both the reaction of methanation and methane reforming. The LDHs displayed compositional flexibility, small crystal sizes, high surface area and excellent basic properties. In this paper, we review previous works of LDHs applied in the reaction of both methanation and methane reforming, focus on the LDH-derived catalysts, which exhibit better catalytic performance and thermal stability than conventional catalysts prepared by impregnation method and also discuss the anti-coke ability and anti-sintering ability of LDH-derived catalysts. We believe that LDH-derived catalysts are promising materials in the heterogeneous catalytic field and provide new insight for the design of advance LDH-derived catalysts worthy of future research.
\end{abstract}

Keywords: layered double hydroxides; two-dimensional materials; methanation reaction; methane reforming; $\mathrm{C} 1$ chemistry

\section{Introduction}

$\mathrm{CH}_{4}$ as a valuable ingredient of natural gas, biogas and coal mine gas plays a prestigious role in $\mathrm{C} 1$ chemistry. $\mathrm{CH}_{4}$ utilization is an important method to utilize greenhouse gas to protect resources and the environment, and methane catalytically-converted into syngas is a preeminent route to synthesize high added-value chemicals from methane [1,2]. The routes for converting methane to syngas include dry reforming of methane (DRM), steam reforming of methane (SRM), partial oxidation of methane (POM) and autothermal reforming (ATM) [3-8]. Among the four kinds of routes for converting methane to syngas, SMR is the most common and renowned economic way to utilize $\mathrm{CH}_{4}$ and produce $\mathrm{H}_{2}$ and have been applied at the industry scale [9]. Besides, POM can obtain a suitable $\mathrm{CO} / \mathrm{H}_{2}$ ratio for methanol synthesis and possesses the advantages of high energy efficiency and mild exothermicity, which exhibit great potential in small reactors that are ideal for decentralized applications [10-12]. When combining SMR and POM, namely autothermal reforming (ATR), exothermic methane oxidation 
can provide energy to endothermic steam reforming, thus a large external supply of heat can be avoided. ATR possesses the superiority of easy reactor temperature control and avoids catalyst sintering and carbon deposition, and a wider range of $\mathrm{H}_{2} / \mathrm{CO}$ ratio can be obtained by manipulating the relative concentrations of $\mathrm{H}_{2} \mathrm{O}$ and $\mathrm{O}_{2}$, as well [13-15]. Furthermore, $\mathrm{CH}_{4}$ can also be obtained by $\mathrm{CO} / \mathrm{CO}_{2}$ methanation, which is a tremendously effectual technology for $\mathrm{CO}_{2}$ valorization and processes for coal-derived natural gas production. $\mathrm{CO}$ methanation is an effective way to produce $\mathrm{CH}_{4}$, and the clean utilization of coal in regions abundant in coal and lacking natural gas has been realized [16,17]. Additionally, $\mathrm{CO}_{2}$ methanation plays an important role in the "power to gas" process and also is an efficient method to produce $\mathrm{CH}_{4}$ and mitigate $\mathrm{CO}_{2}$ emissions, which comprise one of the main sources of global warming [18-23]. Layered double hydroxides (LDHs) have a general molecular formula of $\left[\mathrm{M}(\mathrm{III})\left({ }_{1 \mathrm{x}}\right) \mathrm{M}(\mathrm{III})_{\mathrm{x}}(\mathrm{OH})_{2}\right]^{\mathrm{x}+}\left[\mathrm{A}_{\mathrm{x} / \mathrm{n}}{ }^{\mathrm{n}-}\right] \cdot \mathrm{mH}_{2} \mathrm{O}$, where $\mathrm{M}(\mathrm{II})$ represents divalent cations (e.g., $\mathrm{Mg}$, $\mathrm{Ni}$, etc.), $\mathrm{M}(\mathrm{III})$ is trivalent cations (e.g., $\mathrm{Al}, \mathrm{Fe}$, etc.) and $\mathrm{A}^{\mathrm{n}-}$ denotes anions [24]. LDHs possess compositional flexibility due to the changeable composition and possess a "memory effect" [25-30]. The "memory effect", i.e., after mild thermal treatment, of LDHs can be reconstructed when contacting the solutions containing various anions [31]. LDH-derived catalysts can form homogeneous mixtures of oxides with a small crystal size, which are stable to thermal treatments and eventually exhibit high thermal stability during high temperature reactions [32]. Due to the high thermal stability and high extent of dispersion of metallic particles, redox stability and Lewis acidity, LDH precursor-derived mixed metal oxides are considered also as qualified supports or catalysts for heterogeneous catalysis.

The active components of catalysts for methanation and methane reforming are similar or equivalent, and the similar reactions are highly exothermic, so conventional supported catalysts easily sinter at high temperatures, leading to catalytic deactivation [33]. The active component can be supported on the surface of LDHs or act as a component of LDHs and form a periclase-like structure to restrain the active component Ni's agglomeration [34]. LDH-derived catalysts exhibit good thermo-stability and have been widely studied in $\mathrm{CO} / \mathrm{CO}_{2}$ methanation and methane reforming, which exhibit excellent catalytic performance, as well as anti-coke and anti-sintering abilities. In this paper, a critical review of LDH-derived catalysts for both methanation and methane reforming has been carried out. The catalytic performance, thermal stability, anti-coke and anti-sintering abilities of such catalysts will be discussed assiduously. We believe that the LDH-derived catalysts are promising for the methanation and methane reforming in C1 chemistry.

\section{Methanation}

\subsection{CO Methanation}

The methanation reaction is an ideal way for the coal-derived natural gas production process, for which the catalyst is the key. The reaction of CO methanation is described in Equation (1) [35].

$$
3 \mathrm{H}_{2}+\mathrm{CO} \rightarrow \mathrm{CH}_{4}+\mathrm{H}_{2} \mathrm{O} \Delta \mathrm{H}=-206.28 \mathrm{~kJ} \mathrm{~mol}^{-1}
$$

Ni-based catalysts are the most suitable catalysts when taking catalytic performance and cost into consideration [36]. Metallic oxides $\left(\mathrm{Al}_{2} \mathrm{O}_{3}, \mathrm{MgO}, \mathrm{TiO}_{2}, \mathrm{ZrO}_{2}, \mathrm{CeO}_{2}\right.$, etc. $)$ and molecular sieves (MCM-41, SBA-15, etc.) have been employed to act as support for CO methanation catalysts and exhibit good catalytic performance [37-39]. However, many traditional supported Ni-based catalysts always possess poor dispersion of the active component and deactivation at high temperatures due to coke formation and active component sintering [40,41]. LDH-derived catalysts show high surface area, uniform metal dispersion and a good thermal property and have been used as catalysts for oxidation of methane, hydrogen production from ethanol and CO methanation, as summarized in Figure 1 [42].

$\mathrm{Ni}$-Al LDH-derived catalysts have been deeply investigated and are well known for CO methanation. In 1994, Rathouskf et al. [43] formulated NiAl-CO $\mathrm{CO}_{3} \mathrm{LDH}$-derived mixed oxide (NiAl-LDO) as the $\mathrm{CO}$ methanation catalyst, which maintained excellent activity for the methanation reaction under $2 \mathrm{MPa}$ and $527^{\circ} \mathrm{C}$. The NiAl-LDO catalyst with $56.5 \mathrm{wt} \% \mathrm{Ni}$ achieved $97 \%$ of $\mathrm{CO}$ conversion in the 
pilot methanation unit. Except for the co-precipitation method, the urea hydrolysis method is also an effective route for preparing Ni/Al LDH. Meanwhile, Bian et al. [35] synthesized Ni/Al LDH through the urea hydrolysis method, and the resulting NiAl-LDO catalyst displayed higher catalytic stability due to higher $\mathrm{Ni}$ dispersion and stronger resistance to coke deposition compared with the impregnated catalyst. Nearly 100\% CO conversion was achieved under reaction temperatures between 400 and $500{ }^{\circ} \mathrm{C}$ with a gaseous hourly space velocity (GHSV) of $300,000 \mathrm{~mL} \mathrm{~g}^{-1} \mathrm{~h}^{-1}$.

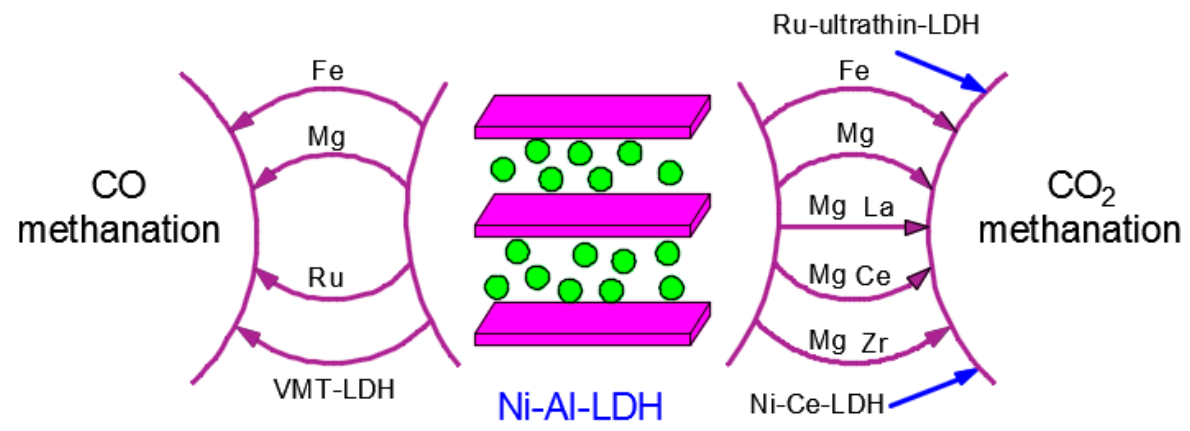

Figure 1. The applications of layered double hydroxides (LDHs) in $\mathrm{CO}$ and $\mathrm{CO}_{2}$ methanation.

However, in the methanation reaction, Ni/Al LDHs also have some drawbacks; for instance, the high nickel content could lead to nickel sintering and carbon deposition during long-term operation [44,45]. Promoters can be released as a drawback, and Hwang et al. [46] reported that the performance of mesoporous nickel-M-alumina xerogel catalysts can be enhanced by introducing a promoter. They found that the yield for $\mathrm{CH}_{4}$ decreased in the order of $30 \mathrm{Ni10FeAX}$ $>$ 30Ni10NiAX > 30Ni10CoAX > 30Ni10CeAX > 30Ni10LaAX. The 30Ni10FeAX catalyst exhibited the optimal $\mathrm{CO}$ dissociation energy and largest $\mathrm{H}_{2}$ adsorption ability, which played a key role in determining the catalytic performance, and thus, Fe was regarded as the most suitable second metal component. The 30Ni10FeAX catalyst achieved 99.4\% CO conversion and $79.1 \% \mathrm{CH}_{4}$ yield at $230{ }^{\circ} \mathrm{C}$. Kustov et al. [47] evaluated the influence of the $\mathrm{Ni} / \mathrm{Fe}$ ratio and the total metal loading on catalytic performance. Two series of mono- and bi-metallic Ni-Fe catalysts were prepared and the catalytic properties tested, among which $25 \mathrm{Fe} 75 \mathrm{Ni}$ catalysts were the most active in $\mathrm{CO}$ hydrogenation for the $\mathrm{MgAl}_{2} \mathrm{O}_{4}$ support at low metal loadings. The maximum performance of $25 \mathrm{Fe} 75 \mathrm{Ni}$ catalysis could be obtained at $20 \mathrm{wt} \%$ total metal loading, exhibiting $100 \% \mathrm{CO}$ conversion and $99.1 \% \mathrm{CH}_{4}$ selectivity at $275{ }^{\circ} \mathrm{C}$ under a GHSV $=50,000 \mathrm{~h}^{-1}$.

Besides, Mg adulteration can improve the anti-coke ability of $\mathrm{Ni} / \mathrm{Al}$ LDHs. Li et al. [48] synthesized $\mathrm{Ni} / \mathrm{Mg} / \mathrm{Al} \mathrm{LDHs}$ through the co-precipitation method, and the as-obtained NiMg8 $(\mathrm{Ni} / \mathrm{Mg}=1 / 8)$ catalyst with 11 wt $\% \mathrm{Ni}$ content achieved the best $\mathrm{CO}$ methanation performance due to the small size of $\mathrm{Ni}$ particles, a higher extent of $\mathrm{Ni}$ dispersion and the strong interaction between $\mathrm{Ni}$ and $\mathrm{MgO}$ and/or $\mathrm{Al}_{2} \mathrm{O}_{3}$ leads to form $\mathrm{Ni}_{\mathrm{x}} \mathrm{Mg}_{1-\mathrm{x}} \mathrm{O}$ solid solution during calcination treatment of the $\mathrm{Ni} / \mathrm{Mg} / \mathrm{Al} \mathrm{LDH}$ precursor; both properties benefited NiMg8 catalyst, exhibiting an excellent performance. $\mathrm{NiMg} 8$ catalyst achieved $99.8 \% \mathrm{CO}$ conversion and $73.6 \% \mathrm{CH}_{4}$ selectivity at $550{ }^{\circ} \mathrm{C}$. In our previous work, we have the spent liquor after mixed-acid etching of vermiculite (VMT) (Figure 2), which mainly contained $\mathrm{Mg}^{2+}$ and $\mathrm{Al}^{3+}$, to synthesize a VMT-derived LDH (VMT-LDH) and prepared $\mathrm{Ni} /$ VMT-LDO through the impregnation method. Due to Fe and Ca modification and the improved dispersion of nickel, Ni/VMT-LDO catalyst had smaller Ni nanoparticles than Ni/MgAl-LDO catalyst, leading to better performance than Ni/MgAl-LDO. Compared with Ni/MgAl-LDO, Ni/VMT-LDO catalyst shoed good low temperature activity and achieved $87.9 \% \mathrm{CO}$ conversion, as well as $90 \% \mathrm{CH}_{4}$ selectivity at $400{ }^{\circ} \mathrm{C}[34]$.

In addition, noble metal doping can not only enhance the $\mathrm{NiO}$ reducibility to generate active sites, but also can act as an active component itself, which was favorable for $\mathrm{CO}$ methanation. Concurrently, Mohaideen et al. [42] added $1 \mathrm{wt} \% \mathrm{Ru}$ to NiAl-mixed metal oxides, and the as-obtained catalyst has 
small $\mathrm{Ru}$ particles, which modified the interaction between $\mathrm{Ru}$ and $\mathrm{Ni}$, increased the reducibility of $\mathrm{NiO}$ and generated more active sites for the $\mathrm{CO}$ methanation reaction. Subsequently, $\mathrm{Ru} / \mathrm{NiAl}-\mathrm{C}$ catalysts achieved a CO conversion of almost $100 \%$ in the temperature range from $150-220{ }^{\circ} \mathrm{C}$. Catalytic performance of $\mathrm{CO}$ methanation for different catalysts in different works were summarized in Table 1.
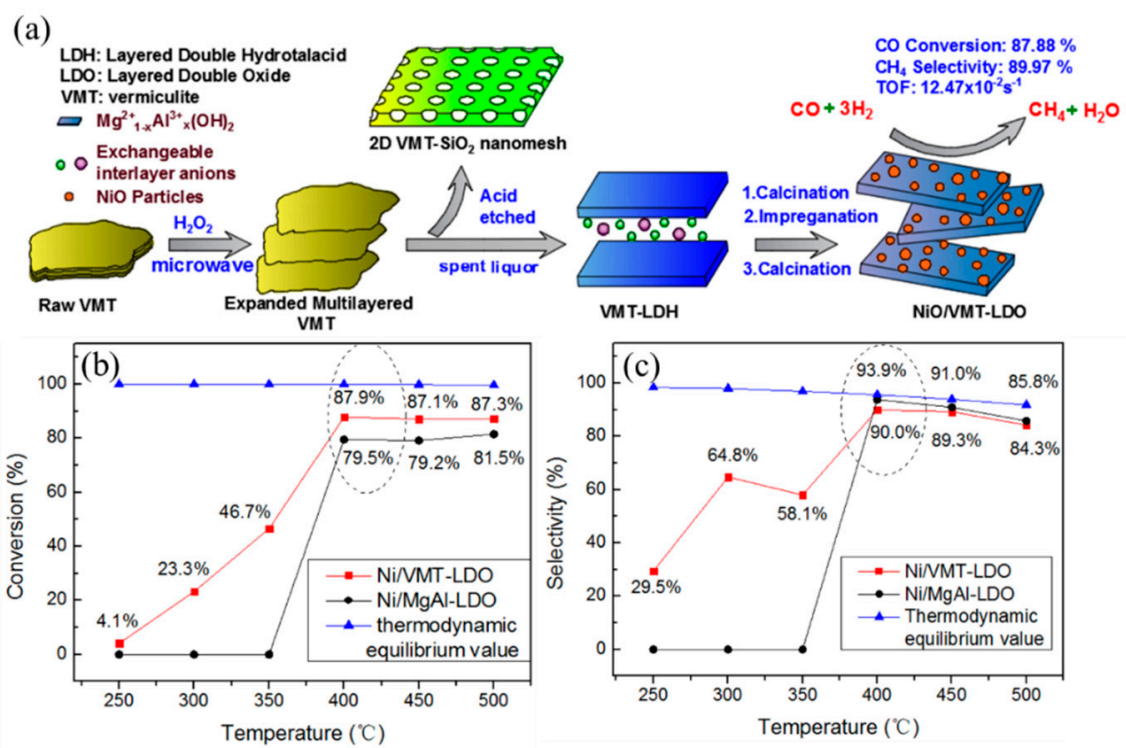

Figure 2. (a) Schematic of the preparation process of $\mathrm{NiO} / \mathrm{VMT}-\mathrm{LDO}$ and $(\mathbf{b}, \mathbf{c})$ the catalytic performance of Ni/VMT-LDO [34].

Table 1. Catalytic performance of CO methanation for different catalysts in different works.

\begin{tabular}{|c|c|c|c|c|c|c|c|}
\hline Catalyst & $\begin{array}{c}\mathrm{Ni} \\
(w \mathrm{t} \%)\end{array}$ & $\begin{array}{c}\text { Temperature } \\
\left({ }^{\circ} \mathrm{C}\right)\end{array}$ & $\begin{array}{l}\text { Pressure } \\
\text { (MPa) }\end{array}$ & $\begin{array}{c}\text { GHSV } \\
\left(\mathrm{mL} \mathrm{g}^{-1} \mathrm{~h}^{-1}\right)\end{array}$ & $\begin{array}{c}\text { CO } \\
\text { Conversion } \\
(\%)\end{array}$ & $\begin{array}{c}\mathrm{CH}_{4} \\
\text { Selectivity } \\
(\%)\end{array}$ & Ref. \\
\hline NiMg8 & 11 & 550 & 0.1 & $15,000 \mathrm{~h}^{-1}$ & 99.8 & 73.6 & [48] \\
\hline $\mathrm{Ru} / \mathrm{NiAl}-\mathrm{C}$ & 30 & 150 & 0.1 & $2400 \mathrm{~h}^{-1}$ & 100 & - & [42] \\
\hline NiAl-LDO & $50 \mathrm{~mol} \%$ & 400 & 0.1 & 300,000 & 100 & 90 & [35] \\
\hline Ni/VMT-LDO & 10 & 400 & 1.5 & 20,000 & 87.9 & 90 & [34] \\
\hline 30Ni10FeAX & 30 & 230 & 1 & 8160 & 99.4 & 79.6 & [46] \\
\hline $25 \mathrm{Fe} 75 \mathrm{Ni}$ & 5 & 275 & - & $50,000 \mathrm{~h}^{-1}$ & 100 & 99.1 & [42] \\
\hline
\end{tabular}

\section{2. $\mathrm{CO}_{2}$ Methanation}

$\mathrm{CO}_{2}$ methanation is one of the most eloquent technologies for $\mathrm{CO}_{2}$ valorization and played an important role in the "power to gas" process [48]. The equation of CO methanation is as follows [35,49]:

$$
4 \mathrm{H}_{2}+\mathrm{CO}_{2} \rightarrow \mathrm{CH}_{4}+2 \mathrm{H}_{2} \mathrm{O} \Delta \mathrm{H}=-164.94 \mathrm{~kJ} \mathrm{~mol}^{-1}
$$

The active components and supports of catalysts for $\mathrm{CO}$ methanation and $\mathrm{CO}_{2}$ methanation are similar or equivalent; similar to $\mathrm{CO}$ methanation, metallic oxides $\left(\mathrm{Al}_{2} \mathrm{O}_{3}, \mathrm{MgO}, \mathrm{TiO}_{2}, \mathrm{ZrO}_{2}, \mathrm{CeO}_{2}\right.$, etc. are used as catalysts [21,50-54]. However, similar to the $\mathrm{CO}$ methanation catalyst, the main concern is catalyst sintering and carbon deposition, and LDH-derived Ni catalysts present good resistance to coking and sintering under methanation of $\mathrm{CO}$ at high temperatures; LDH-derived catalysts are also potential catalysts for $\mathrm{CO}_{2}$ methanation.

Similar to $\mathrm{CO}$ methanation, $\mathrm{Ni}-\mathrm{Al} \mathrm{LDH}$ was also a commonly-used catalyst. Abate et al. [50] synthesized $\mathrm{Ni}-\mathrm{Al} \mathrm{LDH}$ through the co-precipitation method for $\mathrm{CO}_{2}$ methanation. The as-obtained catalyst exhibited better performance compared with commercial catalysts due to the higher metal surface area and metal dispersion. Ni-Al12 catalyst, which was prepared at a $\mathrm{pH}$ of 12 , has achieved 
$86 \% \mathrm{CO}_{2}$ conversion at $300{ }^{\circ} \mathrm{C}$, with a GHSV of $5000 \mathrm{~h}^{-1}$. Gabrovska et al. [51] revealed that the sample with $\mathrm{Ni} / \mathrm{Al}=3$ exhibited the highest conversion during all the reactions after reduction at 400 and $450{ }^{\circ} \mathrm{C}$, while the catalyst of $\mathrm{Ni} / \mathrm{Al}=0.5$ surpassed the catalytic performance of $\mathrm{Ni} / \mathrm{Al}=3$ after reduction within $530-600{ }^{\circ} \mathrm{C}$ due to the increase of $\mathrm{Ni}^{0}$ dispersion.

The precipitation rate and agglomerates varied with hydrophilic colloids, which resulted in diverse metal particle size and further influenced the catalytic performance. The precipitation rate of $\mathrm{NaOH}, \mathrm{NH}_{4} \mathrm{OH}, \mathrm{Na}_{2} \mathrm{CO}_{3}$ and $\left(\mathrm{NH}_{4}\right)_{2} \mathrm{CO}_{3}$ was different; precipitation rate of hydrophilic colloids in $\mathrm{Na}^{+}$-based liquors was faster than that in $\mathrm{NH}^{4+}$-based liquors; and the metal particle size of the as-obtained catalysts decreased in the order of NiFeAl-NaOH $>\mathrm{NiFeAl}-\mathrm{NH}_{4} \mathrm{OH}>\mathrm{NiFeAl}-\mathrm{Na}_{2} \mathrm{CO}_{3}$ $>\mathrm{NiFeAl}-\left(\mathrm{NH}_{4}\right)_{2} \mathrm{CO}_{3}$. The increasing order of different catalysts performance is NiFeAl-NaOH $<$ $\mathrm{NiFeAl}-\mathrm{NH}_{4} \mathrm{OH}<\mathrm{NiFeAl}-\mathrm{Na}_{2} \mathrm{CO}_{3}<\mathrm{NiFeAl}-\left(\mathrm{NH}_{4}\right)_{2} \mathrm{CO}_{3}$ [55]. ( $\mathrm{Ni}, \mathrm{Mg}, \mathrm{Al}$ )-LDH-derived catalyst was first used as a $\mathrm{CO}_{2}$ methanation catalyst by Bette et al. [56]. The as-prepared catalyst reached a maximum of $(74 \pm 2) \%$ between 330 and $350{ }^{\circ} \mathrm{C}$. Mg-Al oxide-supported $\mathrm{Ni}$ catalyst also displayed better performance than $\mathrm{Ni} / \mathrm{MgO}$ and $\mathrm{Ni} / \mathrm{Al}_{2} \mathrm{O}_{3}$ catalysts in $\mathrm{CO}+\mathrm{CO}_{2}$ methanation. The stronger interaction between the support and active component led to excellent thermal stability during the $\mathrm{CO}$ $+\mathrm{CO}_{2}$ methane reaction. Such a catalyst achieved a $98.4 \% \mathrm{CH}_{4}$ yield at $250{ }^{\circ} \mathrm{C}$ and maintained a $95.2 \%$ $\mathrm{CH}_{4}$ yield at $700{ }^{\circ} \mathrm{C}$ for $8 \mathrm{~h} \mathrm{[57]}$.

In pursuit of further improvement of the anti-coke ability of ( $\mathrm{Ni}, \mathrm{Mg}, \mathrm{Al})-\mathrm{LDH}$-derived catalysts, some dopants were introduced. La adulteration of $\mathrm{Mg}$-Al-Ni LDH-derived catalysts can form a periclase-like structure and new medium strength basic sites, promote the $\mathrm{CO}_{2}$ adsorption capacity of the catalysts, soften the interaction between Ni-species and the $\mathrm{LDH}$ matrix and improve $\mathrm{CO}_{2}$ conversion [58,59]. Furthermore, Wierzbicki et al. [59] investigated the effect of the La incorporation method: $\mathrm{Ni}_{21} \mathrm{La}_{0.4}(\mathrm{IE})$ catalyst prepared by ion-exchange displayed the best catalytic performance and achieved $\sim 80 \% \mathrm{CO}_{2}$ conversion at $300{ }^{\circ} \mathrm{C}$, while the impregnation led to a decrease in the amount of medium strength basic sites, while the catalytic performance of $\mathrm{Ni}_{21} \mathrm{La}_{1.1}$ (IMP) had no obvious advantage compared with the $\mathrm{Ni}_{21}$ catalyst. In Nizio et al.'s [60] survey of LDH-derived materials, Ce or Zr adulteration cannot improve the catalytic activity, even though the addition of $\mathrm{Ce}$ or/and $\mathrm{Zr}$ improved the total basicity. In the hybrid plasma-catalytic methanation, the HTNi catalyst exhibited its activity around $80 \%$ conversion at $110{ }^{\circ} \mathrm{C}$, whereas only at relatively high temperatures, Ce-promoted catalysts can show interestingly high activities. Moreover, the author thought the medium-sized zero-valent Ni crystallites of non-promoted HTNi $(15 \mathrm{~nm})$ catalyst seemed to be more active during off plasma methanation than far too small ones $(8.1 \mathrm{~nm}$ of HTNi-CeZr), whereas the influence of the basicity of catalysts on their activity remains relatively unclear. However, plasma-assisted Ni-Ce-LDH-P synthesized catalyst reported by Xu et al. [61] in 2017 exhibited better performance compared to $\mathrm{HTNi}-\mathrm{Ce}$; Ni-Ce-LDH-P achieved almost $75 \% \mathrm{CO}_{2}$ conversion at $270{ }^{\circ} \mathrm{C}$ due to the smaller Ni size, better Ni dispersion and higher alkalinity, whereas Ni-Ce-LDH-C catalyst exhibited the same $\mathrm{CO}_{2}$ conversion at $300{ }^{\circ} \mathrm{C}$. Likewise, characterization results revealed that the precursor of Ni-Ce-LDH-P catalyst presented a lamellar shape, implying the formation of chemical bonds among $\mathrm{Ni}, \mathrm{Ce}$ and $\mathrm{Al}$ (from $\mathrm{Al}_{2} \mathrm{O}_{3}$ ). Actually, it was the chemical bonds that improved the dispersion of $\mathrm{Ni}$ crystal and the interaction between $\mathrm{Ni}$ and $\gamma-\mathrm{Al}_{2} \mathrm{O}_{3}$. Meanwhile, the plasma technology with a relatively low temperature prevented the sintering and agglomeration of Ni during the preparation process.

When the thickness of the material was reduced to the atomic monolayer, the electron density increased, which benefited the high-speed transfer of carrier in the material. This property enabled two-dimensional materials to exhibit great potential in heterogeneous catalysis [62]. Single-layer LDHs (SL-LDHs) drew much more attention recently because of their high performance as energy materials, such as exfoliated NiCo, CoAl and NiFe LDHs [63]. Ren et al. [64] prepared a Ru-loaded ultrathin LDH through ultrasonic exfoliated commercial LDHs in 2016, and the AFM (atomic force microscopy) image showed that the thicknesses of these ultrathin structures were around $8 \AA$, which nearly corresponds to a single basal spacing of the LDH crystals (Figure 3). The as-prepared catalyst had similar wrinkles to 
graphene, and curls existed at the edge and exhibited almost monodispersed Ru nanoparticle or small Ru-nanoparticle aggregates. Ru@FL-LDHs catalyst had the strongest light absorption and exhibited an excellent catalytic performance. Ru@FL-LDHs achieved the highest $\mathrm{CO}_{2}$ conversion of about $96.3 \%$ and $99.3 \%$ of selectivity toward the $\mathrm{CH}_{4}$ in photocatalytic $\mathrm{CO}_{2}$ methanation.

In conclusion, $\mathrm{LDH}$-derived $\mathrm{Ni}$ catalysts were more favorable than traditional impregnated catalysts, while their study in the methanation reaction was limited. As promising catalysts for the methanation reaction, more attention should be paid to future improvement of the catalyst activation and stability, and the reaction mechanism of this kind of catalyst is also worthy of research. Catalytic performance of $\mathrm{CO}_{2}$ methanation for different catalysts in different works were summarized in Table 2 .
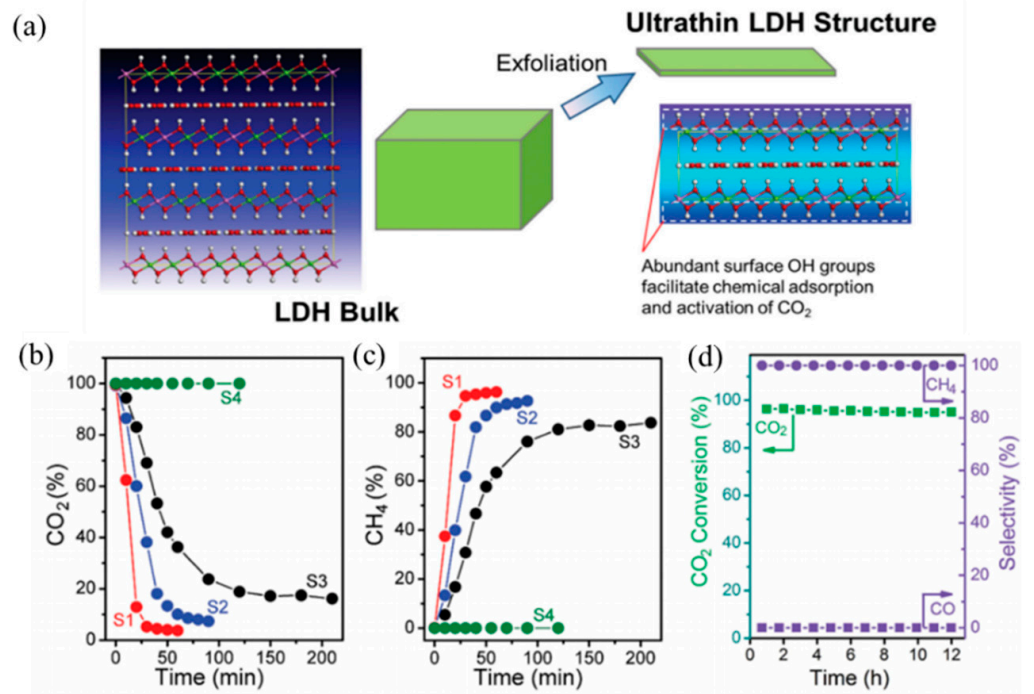

Figure 3. (a) Schematic presence of the formation of the ultrathin LDH structure and (b-d) the catalytic performance of Ru@FL-LDHs [64].

Table 2. Catalytic performance of $\mathrm{CO}_{2}$ methanation for different catalysts in different works.

\begin{tabular}{|c|c|c|c|c|c|c|c|}
\hline Catalyst & $\underset{(w t \%)}{\mathrm{Ni}}$ & $\begin{array}{c}\mathrm{T} \\
\left({ }^{\circ} \mathrm{C}\right)\end{array}$ & $\begin{array}{l}\text { Pressure } \\
\text { (MPa) }\end{array}$ & $\begin{array}{c}\text { GHSV } \\
\left(\mathrm{mL} \mathrm{g}^{-1} \mathrm{~h}^{-1}\right)\end{array}$ & $\begin{array}{c}\mathrm{CO}_{2} \\
\text { Conversion } \\
(\%)\end{array}$ & $\begin{array}{c}\mathrm{CH}_{4} \\
\text { Selectivity } \\
(\%)\end{array}$ & Ref. \\
\hline $\mathrm{Ni} / \mathrm{Mg}-\mathrm{Al}$ & 59 & 330 & 0.1 & 66,000 & 74 & - & [56] \\
\hline $\mathrm{Ni}-\mathrm{Al} 12$ & 76 & 300 & 0.1 & $20,000 \mathrm{~h}^{-1}$ & 86 & 86 (yield) & [21] \\
\hline $\mathrm{NiFeAl}-(\mathrm{NH} 4)_{2} \mathrm{CO}_{3}$ & 30 & 220 & 1 & 9600 & 58.5 & 99.5 & [55] \\
\hline $\mathrm{Ni}_{21} \mathrm{La}_{0.4}(\mathrm{IE})$ & 21 & 300 & - & $12,000 \mathrm{~h}^{-1}$ & 80 & 99.4 & [58] \\
\hline HTNi & 20 & 150 & 0.1 & $20,000 \mathrm{~h}^{-1}$ & 80 & 80 (yield) & [60] \\
\hline Ni-Ce-LDH-P & $\sim 4$ & 270 & - & 60,000 & 75 & 100 & [61] \\
\hline
\end{tabular}

\section{Methane Reforming}

\subsection{Dry Reforming of Methane}

Dry reforming of methane (DRM) is a critical method for obtaining added-value products from $\mathrm{CO}_{2}$ and an effective way to utilize these two greenhouse gases. LDHs are also widely investigated in dry reforming of methane (Figure 4) [6,7]. The equation for the dry reforming of methane (DMR) is as follows [21]:

$$
\mathrm{CH}_{4}+\mathrm{CO}_{2} \rightarrow 2 \mathrm{CO}+2 \mathrm{H}_{2} \Delta \mathrm{H}=247.3 \mathrm{~kJ} \mathrm{~mol}^{-1}
$$

Likewise, two reaction mechanisms of DMR have been surveyed. One mechanism was the Eley-Rideal-type mechanism [65,66]. Methane is firstly adsorbed on the metal and decomposed to $\mathrm{H}_{2}$ 
and adsorbed carbon. Then, the adsorbed carbon is reacted directly with $\mathrm{CO}_{2}$ to yield $\mathrm{CO}$. The equation is as follows:

$$
\begin{aligned}
& \mathrm{CH}_{4} \rightarrow \mathrm{C}(\mathrm{s})+2 \mathrm{H}_{2} \\
& \mathrm{C}(\mathrm{s})+\mathrm{CO}_{2} \rightarrow 2 \mathrm{CO}
\end{aligned}
$$

Additionally, as an alternative reaction mechanism [67-70], methane was decomposed on the metal and produced surface $\mathrm{CH}$ species and hydrogen; carbon dioxide molecules decomposed to $\mathrm{CO}$; and oxygen $(\mathrm{O}(\mathrm{s}))$ adsorbed at the same time. Afterwards, adsorbed oxygen and $\mathrm{CH}$ species reacted to give $\mathrm{CO}$ and $\mathrm{H}_{2}$. The equation is as follows:

$$
\begin{gathered}
\mathrm{CH}_{4} \rightarrow \mathrm{CHx}(\mathrm{s})+(4-\mathrm{x}) / 2 \mathrm{H}_{2} \\
\mathrm{CO}_{2} \rightarrow \mathrm{CO}+\mathrm{O}(\mathrm{s}) \\
\mathrm{CHx}(\mathrm{s})+\mathrm{O}(\mathrm{s}) \rightarrow(\mathrm{x} / 2) \mathrm{H}_{2}+\mathrm{CO}
\end{gathered}
$$

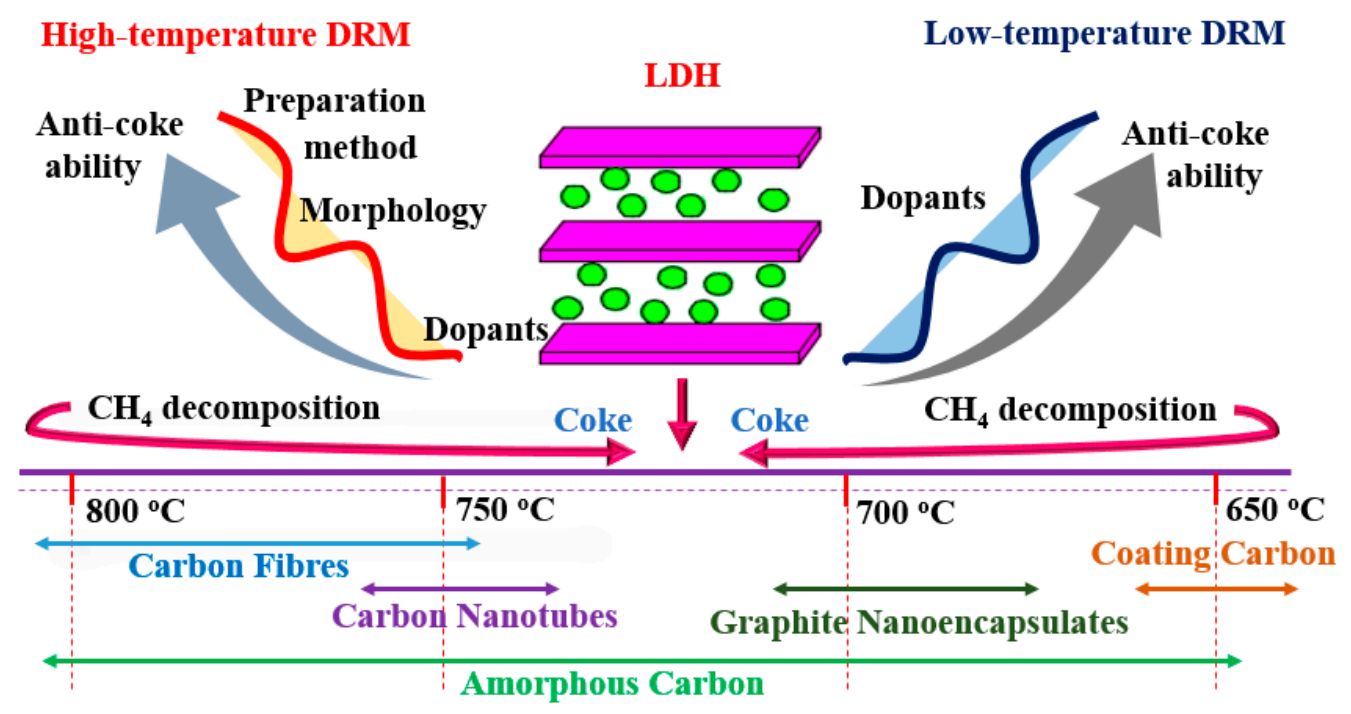

Figure 4. The application of LDHs in dry reforming of methane. DRM, dry reforming of methane.

\subsubsection{High Temperature Dry Reforming of Methane}

Noble metals like Ru reflected excellent catalytic performance and anti-coke deposition ability in the DRM reaction. Supports have great influence on the dispersion of the active component $\mathrm{Ru}$. $\mathrm{Ru}$ metal dispersed on different supports followed the order: $\mathrm{Ru} / \mathrm{Mg}_{3}(\mathrm{Al}) \mathrm{O}>\mathrm{Ru} / \mathrm{MgO}>$ $\mathrm{Ru} / \mathrm{MgAl}_{2} \mathrm{O}_{4}>\mathrm{Ru} / \gamma-\mathrm{Al}_{2} \mathrm{O}_{3} . \mathrm{Ru} / \mathrm{Mg}_{3}(\mathrm{Al}) \mathrm{O}$ catalyst showed higher catalytic performance due to the strong base intensity of support and more surface $\mathrm{Ru}^{0}$ atoms, which ascribed to $\mathrm{Mg}(\mathrm{Al}) \mathrm{O}$ mixed oxide's unique properties, including memory effect, low crystallinity and its strong interaction with $\mathrm{Ru}$ [71]. $\mathrm{Ru} / \mathrm{Mg}_{3}(\mathrm{Al}) \mathrm{O}$ catalyst displayed an $84 \% \mathrm{CH}_{4}$ conversion during the 30-h stability test without any deactivation.

Even though noble metal-based catalysts exhibited excellent catalytic performance, industrial applications were limited due to the high cost. Ni was a suitable active catalyst component when taking catalytic performance and cost into consideration. In 1988, Bhattacharyya et al. [72] investigated the performance of $\mathrm{LDH}$-derived catalysts in $\mathrm{CO}_{2}$ reforming of methane. Compared with commercial $\mathrm{Ni} / \mathrm{Al}_{2} \mathrm{O}_{3}$ catalysts, the LDH-derived $\mathrm{Ni}_{4} \mathrm{Al}_{2} \mathrm{O}_{7}$ catalyst showed identical performance at $815{ }^{\circ} \mathrm{C}$ and 2.07 MPa. LDH-derived catalysts had superior stability and a coke-resistant ability according to aging studies, and the $\mathrm{LDH}$-derived $\mathrm{Mg}_{5} \mathrm{NiAl}_{2} \mathrm{O}_{9}$ catalyst exhibited the highest $\mathrm{CH}_{4}$ conversion of $95.8 \%$ under operation conditions at $850{ }^{\circ} \mathrm{C}, 0.67 \mathrm{MPa}$, GHSV $=14,400 \mathrm{~h}^{-1}$ and $\mathrm{CO}_{2} / \mathrm{CH}=1.25$; while 
Touahra et al. [73] discovered that $\mathrm{Ni} / \mathrm{Al}=2$ was optimal for $\mathrm{Ni}-\mathrm{Al} \mathrm{LDH}$-derived catalysts due to the low $\mathrm{Ni}^{0}$ crystallite size and high stability of the support $\left(\mathrm{NiAl}_{2} \mathrm{O}_{4}\right)$.

Consequently, when $\mathrm{Mg}$ was introduced to $\mathrm{Ni}-\mathrm{Al} \mathrm{LDHs}$, the catalytic performance and anti-coke ability of the catalyst improved. Mette et al. [74-76] found that Ni/MgAlOx catalyst has good anti-coke ability, and the catalytic performance revealed no decrease in performance after 19 times of cycling because nickel aluminate overgrowth on the Ni particles blocked all extended metallic Ni sites, which were nucleation centers for carbon formation. As reported by Lopez et al. [77], the catalytic properties of Ni-Mg-Al catalysts were more affected by the $\mathrm{M}^{\mathrm{II}} / \mathrm{M}^{\mathrm{III}}$ ratio compared with the $\mathrm{Ni} / \mathrm{Mg}$ ratio. When $\mathrm{M}^{\mathrm{II}} / \mathrm{M}^{\mathrm{III}}$ was maintained, the catalyst activity was related to the nickel crystal size and $\mathrm{Ni} / \mathrm{Mg}$ ratio, while selectivity suffered little from the $\mathrm{Ni} / \mathrm{Mg}$ ratios. This notwithstanding, when $\mathrm{Ni} / \mathrm{Mg}$ was constant, the catalyst activity was strongly affected and decreased as the $\mathrm{M}^{\mathrm{II}} / \mathrm{M}^{\mathrm{III}}$ ratio decreased. Besides, Zhu et al. [78] showed that $\mathrm{NiMgAl}$ catalyst with a $\mathrm{Mg} / \mathrm{Al}$ ratio of 1 displayed the best activity and stability during the DRM reaction, and it was the formation of LDH precursors and $\mathrm{MgNiO}_{2}$ that played the key role in stabilization. Interestingly, Li et al. [79] demonstrated that the performance of $\mathrm{Ni} / \mathrm{Mg}(\mathrm{Al}) \mathrm{O}$ catalyst decreased at the beginning due to the $\mathrm{MgO}$ film surrounding the $\mathrm{Ni}$ particles; however, the catalyst was renewed after $\mathrm{MgAl}_{2} \mathrm{O}_{4}$ spinel-like phase formation. TheHT-700 catalyst reached approximately $95 \% \mathrm{CH}_{4}$ conversion after $500 \mathrm{~h}$ of reaction and maintained for $1500 \mathrm{~h}$. In 2016, Buelens et al. [80] developed a "super-dry" $\mathrm{CH}_{4}$ reforming through Le Chatelier's principle reaction (Figure 5): $\mathrm{Ni} / \mathrm{MgAl}_{2} \mathrm{O}_{4}$ was used as the catalyst during the "super-dry" $\mathrm{CH}_{4}$ reforming. $\mathrm{Fe}_{2} \mathrm{O}_{3} / \mathrm{MgAl}_{2} \mathrm{O}_{4}$ was used as the solid oxygen carrier, which oxidized $\mathrm{CH}_{4}$ into $\mathrm{CO}_{2}$ and $\mathrm{H}_{2} \mathrm{O}$. Meanwhile, the $\mathrm{Fe}_{2} \mathrm{O}_{3}$ reduced to $\mathrm{Fe} ; \mathrm{CaO} / \mathrm{Al}_{2} \mathrm{O}_{3}$ was used as the $\mathrm{CO}_{2}$ sorbent, which formed $\mathrm{CaCO}_{3}$ and then decomposed into $\mathrm{CaO}$ and $\mathrm{CO}_{2}$, and $\mathrm{CO}_{2}$ reduced to $\mathrm{CO}$ by Fe through a redox reaction. "Super-dry" $\mathrm{CH}_{4}$ reforming also resulted in a very low exergy destruction per mole $\mathrm{CO}_{2}$ converted; the exergy destruction for $\mathrm{CO}_{2}$ conversion was up to $25-50 \%$ lower as compared with that of conventional DRM. "Super-dry" $\mathrm{CH}_{4}$ reforming can result in higher $\mathrm{CO}$ production and showed both practical and economic benefits compared with conventional dry reforming.

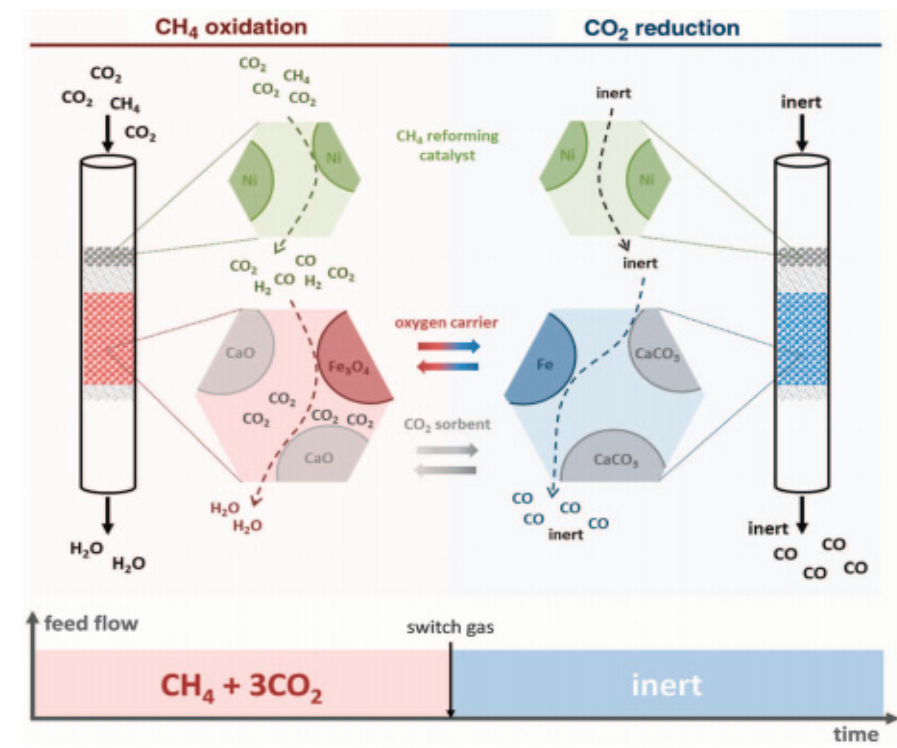

Figure 5. Schematic representation of the "super dry" reforming process [81].

Besides the classic co-precipitation method, other methods also have been employed to prepare high efficiency Ni/Mg/Al LDH-derived catalysts. Meanwhile, Shishido et al. [81] investigated the influence of the preparation method on the catalytic performance of $\mathrm{Ni} / \mathrm{Mg}$ - $\mathrm{Al}$ catalyst. Likewise, the solid phase crystallization (spc) method can promote $\mathrm{Ni}^{2+}$ replacement of the $\mathrm{Mg}^{2+}$ site in $\mathrm{LDH}$, resulting in the formation of highly dispersed 7\% Ni metal particles, while the Ni dispersion of 
imp-Ni/Mg-Al was $4.8 \%$ (prepared by impregnation method). The catalyst spc-Ni/Mg-Al exhibited a slightly better catalytic performance than imp-Ni/Mg-Al at $800{ }^{\circ} \mathrm{C}$. In addition, Chai et al. [82] developed a FeCrAl-fiber-structured nanocomposite $\mathrm{NiO}-\mathrm{MgO}-\mathrm{Al}_{2} \mathrm{O}_{3}$ catalyst in one step, using a $\gamma-\mathrm{Al}_{2} \mathrm{O}_{3} /$ water interface-assisted method, as shown in Figure 6. The as-obtained catalyst exhibited excellent stability due to $\mathrm{Ni}$ nanoparticles being uniformly nested in $\mathrm{MgO}-\mathrm{Al}_{2} \mathrm{O}_{3}$ nano-sheet composites after reducing of the catalyst. Difficult carbon deposition was the main cause for catalyst deactivation, and the deactivation rate was significantly decreased as compared with the $\mathrm{Ni} / \mathrm{Al}_{2} \mathrm{O}_{3}$ catalyst. The $\mathrm{NiO}-\mathrm{MgO}-\mathrm{Al}_{2} \mathrm{O}_{3}$ catalyst achieved a $\mathrm{CH}_{4}$ conversion of $91 \%$ at $800{ }^{\circ} \mathrm{C}$ with a GHSV of $5000 \mathrm{~mL} \mathrm{~g}^{-1} \mathrm{~h}^{-1}, \mathrm{CH}_{4} / \mathrm{CO}_{2}=1.0 / 1$. In situ growth of $\mathrm{LDH}$ on $\gamma-\mathrm{Al}_{2} \mathrm{O}_{3}$ is also an effective way to prepare DMR catalysts. The $\mathrm{NiMgAl}-\mathrm{LDO} / \gamma-\mathrm{Al}_{2} \mathrm{O}_{3}$ catalyst has a small Ni nanoparticles size, a strong metal-support interaction and finely-tailored surface basicity. The NiMgAl-LDO $/ \gamma-\mathrm{Al}_{2} \mathrm{O}_{3}$ catalyst achieved an $80.7 \% \mathrm{CH}_{4}$ conversion at $700{ }^{\circ} \mathrm{C}$ and showed outstanding stability during the 48-h test [83]. Zhang et al. [84] reduced LDH by atmospheric cold plasma jet, and the as-obtained C-LDHs $/ \gamma-\mathrm{Al}_{2} \mathrm{O}_{3}$ catalyst can avoid the side-reaction in $\mathrm{CO}_{2}-\mathrm{CH}_{4}$ reforming, leading to better carbon deposition resistance. C-LDHs $/ \gamma-\mathrm{Al}_{2} \mathrm{O}_{3}$ catalyst achieved the same $\mathrm{CH}_{4}$ conversion of $98 \%$ as Ni/MgO/ $\gamma-\mathrm{Al}_{2} \mathrm{O}_{3}$ catalyst at $800^{\circ} \mathrm{C}$, but had higher $\mathrm{H}_{2}$ selectivity.
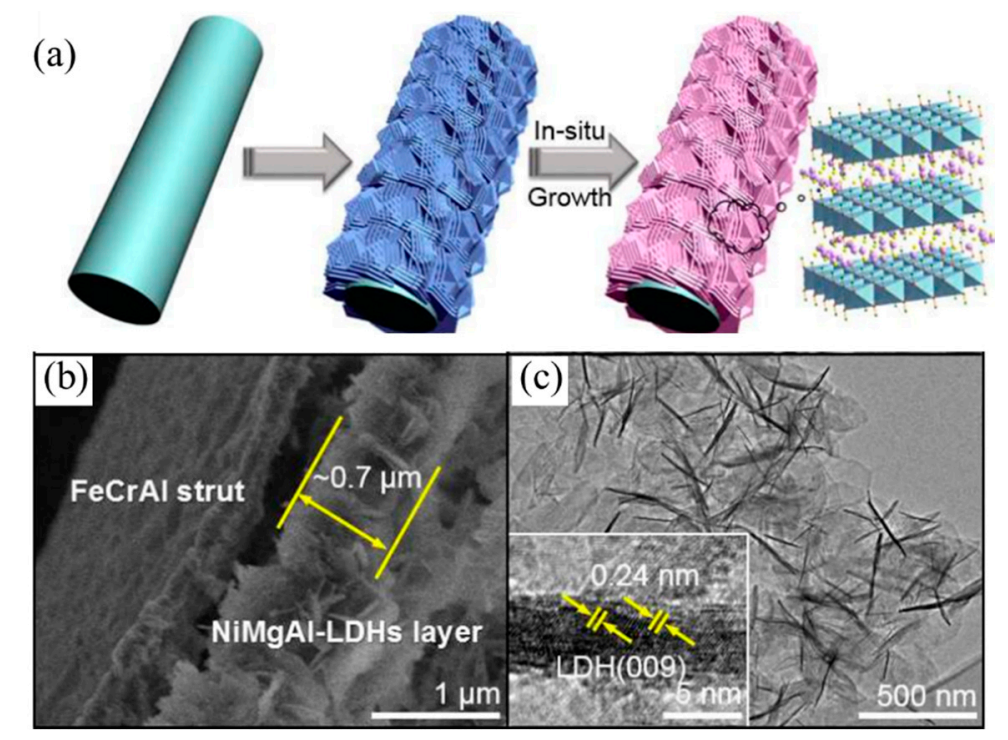

Figure 6. (a) Schematic of microfibrous-structured $\mathrm{NiO}-\mathrm{MgO}-\mathrm{Al}_{2} \mathrm{O}_{3}$ nano-sheets grown on FeCrAl-fiber felt and (b) SEM image and (c) TEM image of NiMgAl-LDHs /FeCrAl-fiber-900 [82].

Besides, the main challenge for NiMgAl LDH-derived catalysts was carbon deposition, and many efforts have been made to overcome this obstacle, such as utilizing metal adulteration and changing the morphology of the catalyst. Noble metal $\mathrm{Rh}$ as a promoter for Ni catalysts can improve the catalyst activity; Rh adulteration increased the amount of reducible $\mathrm{Ni}$ and promoted the dispersion of $\mathrm{Ni}$. In addition, the presence of Rh probably led to Ni segregation with time on stream and generated carbon deposition due to $\mathrm{Rh}$ having favorable $\mathrm{CH}_{4}$ decomposition [85]. Moreover, $\mathrm{Zr}$ adulteration to LDH can form periclase-like mixed oxide and rearrangement of Ni particles during the DRM reaction. The $\mathrm{HNiZr}_{3}$ catalyst exhibited the highest coking resistance properties due to $\mathrm{Zr}$ species in the lattice of periclase-like mixed oxide, resulting in small $\mathrm{Ni}$ crystallites, which are inactive in direct methane and Boudouard reaction oxides. Yet, $\mathrm{Zr}$ adulteration decreased the activity, and the $\mathrm{CH}_{4}$ conversion of HT-25Ni catalyst was $40 \%$ and $23 \%$ for HTNi-Zr catalyst [86]. La as a promoter can improve nickel metal dispersion and increase the total amount of basic sites and surface Ni content [87]. With $1.1 \mathrm{wt} \%$ La adulteration, the catalyst properties vary as the $\mathrm{Mg} / \mathrm{Al}$ molar ratio changes, and the higher $\mathrm{Mg} / \mathrm{Al}$ molar ratio enhanced the catalyst stability with fewer carbon deposition, but decreased 
activity. The best stability was achieved at $\mathrm{Mg} / \mathrm{Al}=3$ during a $120-\mathrm{h}$ test, and the hydro-magnesite phase was formed with a $\mathrm{Mg} / \mathrm{Al}$ molar ratio of four [88-91].

Ce as a promoter has been revealed by Daza et al. [92-94], who explored two adulteration methods. Ce promoted by the co-precipitation method at constant $\mathrm{pH}$ formed mixed reducible phases of the $\mathrm{NiO}-\mathrm{MgO}$ (periclase) type and $\mathrm{CeO}_{2}$ (fluorite), and the as-obtained catalyst exhibited better performance than the un-promoted catalyst. $\mathrm{OM}_{2}$ (Ce-NiMgAl-LDO) catalyst with $14.9 \% \mathrm{CeO}_{2}$ displayed about a $75 \% \mathrm{CH}_{4}$ conversion during the 200-min reaction, and the $\mathrm{CO}_{2}$ conversion was also about $10 \%$ higher than that of OM1 (NiMgAl-LDO) catalyst, which contained no $\mathrm{CeO}_{2}$. Further study revealed that $\mathrm{Ce}$ and $\mathrm{Mg}$ had a synergic effect on the $\mathrm{CO}_{2}$ adsorption capacity of the solids, promoted the basicity of oxides and enhanced their catalytic activity in $\mathrm{CO}_{2}$ reforming of methane. However, high loads of Ce decreased the superficial area of the solid and favored the formation of free $\mathrm{NiO}$, which had a negative impact on the selectivity and increased the formation of coke. The fact-finding of Djebarri et al. [95] insinuated that the NiMgCe catalyst was a very stable, and a poorly-reducible mixed oxide phase was formed with Ce adulteration, which inhibited the catalysts' catalytic performance. Besides, the Ce addition affected the catalytic performance. Ren et al. [96] unveiled that Ce introduced through the incipient impregnation method showed higher $\mathrm{Ce}^{3+}$ content and appropriate interactions between Ni and NMA compared with catalyst prepared by the co-precipitation method. Daza et al. [97] also revealed that with Ce introduced by partial reconstruction, the as-prepared catalyst formed periclase and fluorite mixed phases after the calcination, and the reconstruction took place at the external edges of the oxide granules. Ce presented an improvement in the degree of reduction of $\mathrm{Ni}$, the amount and strength of the basic sites. With Ce loading increased, no obvious considerable differences in the catalytic activity and selectivity were perceived, but the anti-coke ability was improved. The optimal amount of Ce doping was $3 \mathrm{wt} \%$, and OM3 (Ce-NiMgAl-LDO) catalysts with $(\mathrm{Ni}+\mathrm{Mg}) / \mathrm{Al}=3$ ) achieved a $90.3 \% \mathrm{CH}_{4}$ conversion at $700{ }^{\circ} \mathrm{C}$, with the $\mathrm{CO}_{2} / \mathrm{CH}_{4} / \mathrm{He}$ ratio of 20/20/60 and weight hourly space velocity (WHSV) $=48 \mathrm{~L} \mathrm{~g}^{-1} \mathrm{~h}^{-1}$.

Additionally, the anti-coke ability can also be improved through incorporating carbon in the Ni-based catalyst. In 2017, Jin et al. [33] used sucrose as the carbon source to incorporate carbon in the Ni-based catalyst, and carbon incorporation formed new mesopores, increased the specific surface area and inhibited Ni particle growth. The as-prepared PC-350-1.8 (pretreated catalyst) catalyst exhibited relatively lower initial conversions of $\mathrm{CH}_{4}$ and $\mathrm{CO}_{2}$ than pure Ni-LDO catalyst, but showed excellent anti-coke ability. The R-C-350-1.8-800 catalyst was obtained by removing the upper carbon from PC-350-1.8 catalyst, displaying 10\% higher $\mathrm{CH}_{4}$ conversion and showing slightly lower carbon deposition.

Besides transition elements and rare-earth elements, the advantage of the coke resistance ability changed the morphology of the catalysts and can also promote the anti-carbon deposition ability. $\mathrm{Du}$ et al. [98] synthesized monolithic Ni-Mg-Al LDH catalyst nanosheets via in situ growth on $\mathrm{Al}$ wires. The as-prepare catalyst showed a hierarchical porous structure, and the oxide nanosheets were arranged as a dense film on the aluminum substrate. Monolithic catalysts showed strong metal-support interactions and strong basic sites compared with traditional Ni-MgO- $\mathrm{Al}_{2} \mathrm{O}_{3}$ catalysts. The monolithic catalysts have also displayed excellent sintering resistance and anti-carbon deposition ability, and coke deposition on the monolithic catalysts was one third that on the traditional catalysts. $\mathrm{Du}$ et al. [99] also developed a modular catalyst by combining the $\mathrm{Ni}-\mathrm{MgO}-\mathrm{Al}_{2} \mathrm{O}_{3}$ mixed oxide nanoplates with the mesoporous $\mathrm{SiO}_{2}$ coating, the as-prepared $\mathrm{NiMgAl}-\mathrm{LDH} @ \mathrm{~m}-\mathrm{SiO}_{2}$ catalyst core shell structure (Figure 7) and the dual confinement effects: The first confinement was $\mathrm{MgO}$, which can promote embedded Ni NP dispersion and enhance the chemisorption ability of $\mathrm{CO}_{2}$, as well as restrain the carbon deposition and Ni NP aggregation. The second confinement resulted from the mesoporous $\mathrm{SiO}_{2}$ shell, which exhibited another "confinement effect". These two confinement effects can reinforce each other, which enabled the modular catalysts to show excellent anti-coke and sintering resistance ability. IR-NiMgAl-LDH@m-SiO 2 achieved a $90 \% \mathrm{CH}_{4}$ conversion at $800{ }^{\circ} \mathrm{C}$, much higher than that of the IM-NiMgAl-LDH@m-SiO $2(\sim 55 \%)$ catalyst obtained by the impregnation method. 
Gonzáleza et al. [100] made a Ni-Mg-Al nano-spheroid oxide catalyst through the sol-gel method, and this nano-spheroid oxide catalyst with 15 wt \% $\mathrm{Ni}$ achieved a $95 \% \mathrm{CH}_{4}$ conversion at $800{ }^{\circ} \mathrm{C}$ and showed excellent long-term stability. Amorphous carbon formed on the nano-spheroid catalyst surface during the reaction, which seemed not to be detrimental to this reaction. Encapsulation of carbon is the main culprit in the nickel-containing catalyst's deactivation, because the nickel crystallites are encapsulated by the carbon. However, for this nano-spheroid catalyst, the majority of the carbon was amorphous, and a few seeds of encapsulated carbon benefited from the good conformation of the active sites formed by the nano-crystalline structure of the mixed oxides $\mathrm{Mg}(\mathrm{Al}, \mathrm{Ni}) \mathrm{O}$. In this regard, combining $\mathrm{Mg}$-Al mixed oxides with SBA-15 is also an effective way to improve the anti-coke ability. Zuo et al. [101] found that the catalyst whose metal oxides were calcined two times showed excellent anti-carbon deposition and catalytic stability, due to the strong metal-support interaction and the channel local effect of SBA-15. The SH-550 (SBA-15 added to the hydrotalcite suspension during the preparation) and HS-550 (hydrotalcite added to the SBA-15 suspension during the preparation)catalysts, for which the metal oxides have been calcined two times, achieved almost an $85 \%$ $\mathrm{CH}_{4}$ conversion and maintained excellent stability at $800^{\circ} \mathrm{C}$. For the HS-550 catalyst, the $\mathrm{Ni}^{0}$ particles were isolated from one another, so that the clustering of $\mathrm{Ni}$, which is necessary for coke formation, was prevented. In addition, the HS-550 catalyst contained two nickel species: $\mathrm{Ni}^{0}$ and $\mathrm{NiO}$; the coexistence of these two species favored the high catalyst activity reported by Damyanova et al. [102].
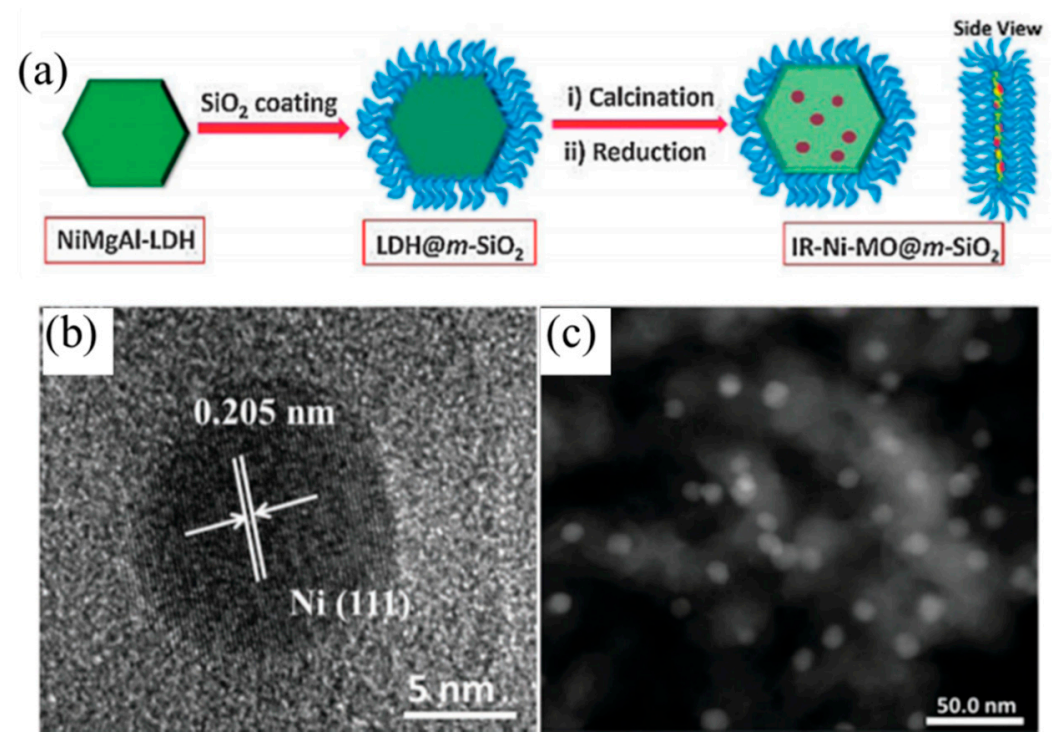

Figure 7. (a) Schematic illustration of the preparation process of the modular catalysts. (b) TEM image and (c) HAADF-STEM image of the modular catalysts [99].

Furthermore, Co was also an active component of DRM reforming, and Co containing LDH has been used as the DRM catalyst. Liu et al. [103] discovered that the catalytic activity, stability and coke resistance of $\mathrm{Co} / \mathrm{MgAl}$ increased with the increase of Co loading, and the $12 \% \mathrm{Co} / \mathrm{Mg}_{3} \mathrm{Al}$ catalyst showed much higher catalytic stability and much less coke deposition at $600{ }^{\circ} \mathrm{C}$ as compared to the $12 \%$ $\mathrm{Ni} / \mathrm{Mg}_{3} \mathrm{Al}$ catalyst, which may be attributed to the higher affinity of Co for oxygen species; in addition, Co has a higher interaction with support. The results suggested that Co has the potential compared to $\mathrm{Ni}$ to be an active catalyst in the $\mathrm{CH}_{4}-\mathrm{CO}_{2}$ reforming reaction. In Gennequin et al.'s study [104], the $\mathrm{Co}_{2} \mathrm{Mg}_{4} \mathrm{Al}_{2} \mathrm{HT} 500$ catalyst exhibited better stability as compared with the $\mathrm{Co}_{4} \mathrm{Mg}_{2} \mathrm{Al}_{2} \mathrm{HT} 500$ catalyst, though the $\mathrm{Co}_{2} \mathrm{Mg}_{4} \mathrm{Al}_{2} \mathrm{HT} 500$ catalyst has a lower initial activity. The $\mathrm{Co}_{6} \mathrm{Al}_{2} \mathrm{HT} 500$ catalyst showed comparable catalytic performance to the $\mathrm{Co}_{2} \mathrm{Mg}_{4} \mathrm{Al}_{2} \mathrm{HT} 500$ catalyst during the stability test, while $\mathrm{Co}_{6} \mathrm{Al}_{2} \mathrm{HT} 500$ showed a larger amount of deposited carbon. After the reaction, three catalysts exhibited a weight decrease corresponding to carbon oxidation following the order: $\mathrm{Co}_{6} \mathrm{Al}_{2} \mathrm{HT} 500$ 
$(-52 \%)>\mathrm{Co}_{4} \mathrm{Mg}_{2} \mathrm{Al}_{2} \mathrm{HT} 500(-23 \%)>\mathrm{Co}_{2} \mathrm{Mg}_{4} \mathrm{Al}_{2} \mathrm{HT} 500$ (-5.5\%). Mg oxides could inhibit coke deposition via adsorbed $\mathrm{CO}_{2}$ species on the basic site and afterwards react with the deposited carbon by the reverse Boudouard reaction. The $\mathrm{Co}_{2} \mathrm{Mg}_{4} \mathrm{Al}_{2} \mathrm{HT} 500$ catalyst has a higher Mg content, thus showing excellent anti-coke deposition stability. It could be concluded that for the reaction of the dry reforming of methane, the catalytic performances of CoxMgyAl ${ }_{2} \mathrm{HT} 500$ solids have a great relation to $\mathrm{Co}$ and $\mathrm{Mg}$ content. Gennequin et al. [105] used the "memory effect" of LDHs to impregnate the $1 \mathrm{wt} \%$ $\mathrm{Ru}$ into CoxMgyAl${ }_{2}$, and the as-obtained catalyst exhibited better performance than the conventional impregnation method in the temperature region of $450-750^{\circ} \mathrm{C}$. Regarding this, small amounts of $\mathrm{Ru}$ can promote the reducibility of cobalt catalysts and enhance the stability of the catalysts via decreased carbon formation; the catalyst obtained by the "memory effect" generated both metallic and basic sites, which are favorable for the dry reforming reaction of methane.

Moreover, Ni-Co bimetallic LDHs were prepared by the in situ synthesized method on the surface of $\gamma-\mathrm{Al}_{2} \mathrm{O}_{3}$. The as-obtained catalysts showed a strong interaction between the active component (Ni and $\mathrm{Co}$ ) and the catalytic support [106]. However, Tanios et al. [107] discovered that the Ni and Co synergistic effect greatly improved the catalytic properties and prevented carbon formation. The $1 \mathrm{Co}-2 \mathrm{Ni}-\mathrm{LDH}$ catalyst exhibited the best catalytic performance and resulted in the least coke, achieving a $98.3 \% \mathrm{CH}_{4}$ conversion that decreased to $1.7 \%$ after $50 \mathrm{~h}$ of reaction at $800{ }^{\circ} \mathrm{C}$, much higher than that of $\mathrm{Co} / \gamma-\mathrm{Al}_{2} \mathrm{O}_{3}$, which resulted in a $56.2 \% \mathrm{CH}_{4}$ conversion and complete deactivation after the 50-h test; while the optimal $\mathrm{Co} / \mathrm{Ni}$ ratio was one when using aluminum nitrate as the trivalent ion source.

\subsubsection{Low Temperature Dry Reforming of Methane}

The DRM reaction was always performed at high temperatures to obtain a better performance, whereas LDHs as the catalyst precursors for low temperature dry reforming of methane were studied by Debek et al. [108]. Ni-Al LDH was firstly used as the catalyst for the dry reforming of methane. The HT-NiAl catalyst reduced at $900{ }^{\circ} \mathrm{C}$ exhibited a $48 \% \mathrm{CH}_{4}$ conversion and about a $55 \% \mathrm{CO}_{2}$ conversion, higher than that of the $\mathrm{HT}-\mathrm{NiAl}$ catalyst reduced at $550{ }^{\circ} \mathrm{C}$, due to the reduction temperature of $550{ }^{\circ} \mathrm{C}$ not being sufficient to reduce all of the nickel species to being metallic. Moreover, the side reaction of $\mathrm{CH}_{4}$ decomposition occurring due to an excess of $\mathrm{H}_{2}$ was observed, and a ca. $30 \%$ conversion of methane was obtained by $\mathrm{CH}_{4}$ on decomposition catalysts reduced at 550 and $900^{\circ} \mathrm{C}$, which evinced that methane decomposition strongly influences the overall process; in addition, the $\mathrm{CH}_{4}$ decomposition was not influenced by the temperature of the catalyst's pre-treatment.

As the active component, the incorporation method and the content of $\mathrm{Ni}$ have a great effect on the DRM reaction. Higher values of $\mathrm{CH}_{4}$ and $\mathrm{CO}_{2}$ conversions were obtained for the sample (HTNi) prepared by the co-precipitation method with $63.47 \mathrm{wt} \% \mathrm{Ni}$ content. About a $55 \% \mathrm{CH}_{4}$ conversion was obtained at $550{ }^{\circ} \mathrm{C}$ for the $\mathrm{HTNi}$ catalyst, and additional catalytic tests were performed on $\mathrm{CH}_{4}$ decomposition on the sample $\mathrm{HTNi}$ at $550{ }^{\circ} \mathrm{C}$ with a feed gas of $\mathrm{CH}_{4} / \mathrm{Ar}=2 / 8$. However, HTexNi catalyst with $0.78 \mathrm{wt} \% \mathrm{Ni}$ displayed higher activity per gram of active material, due to the formation of small Ni NPs or aggregates of nickel oxide on the catalyst surface [109]. Ni particle size increased with $\mathrm{Ni}$ content increasing, and dry reforming of methane and direct methane decomposition showed increased methane conversion. Methane decomposition and carbon formation may occur, especially in the presence of catalysts that contain $\mathrm{Ni}$ in considerable amounts, and the catalysts with different $\mathrm{Ni}$ contents had the same catalytic performance trend as the DRM reaction. Thus, methane decomposition at low temperatures can be controlled by decreasing the Ni particle/crystal size [110].

Because the side reaction of methane decomposition was inevitable during the DRM reaction, methane decomposition led to carbon deposition and catalyst deactivation. Daza et al. [97] found that Ce-promoted catalysts had excellent coke resistance ability. Debek et al. investigated the route cause for this phenomenon. Bigger Ni crystallites on the catalysts with the highest $\mathrm{Ni}$ content promoted direct $\mathrm{CH}_{4}$ decomposition and accelerated catalyst deactivation. Ce-promoted Ni-containing LDH suppressed the side reaction of $\mathrm{CH}_{4}$ decomposition due to its high basicity enhanced $\mathrm{CO}_{2}$ adsorption 
and excellent ability to oxidize the already formed carbon deposits, whereas too high a loading of ceria had a negative effect during the overall process due to the formation of free $\mathrm{NiO}$ [111].

Meanwhile, $\mathrm{Zr}$ doping can further promote the coke resistance ability of catalyst and substantially restrain the extensive formation of fishbone-type carbon nanofibers. With the adulteration of $\mathrm{Zr}$, the $\mathrm{CH}_{4}$ conversion decreased, but $\mathrm{Zr}$ considerably inhibited methane's direct decomposition, favored methane reaction with $\mathrm{CO}_{2}$ (DMR reaction), together with other important parallel reactions, such as the reverse Boudouard reaction. The HT-25Ni catalyst achieved $48 \% \mathrm{CH}_{4}$ conversion and showed $25 \%$ $\mathrm{CH}_{4}$ conversion at $550{ }^{\circ} \mathrm{C}$; even though both $\mathrm{CH}_{4}$ and $\mathrm{CO}_{2}$ conversions of the $\mathrm{HTNi}-\mathrm{CeZr}$ catalyst were low, almost no carbon was deposited on the catalyst surface during $5 \mathrm{~h}$ of DMR reaction [112]. The catalysts with $\mathrm{Ce} / \mathrm{Zr}$ loading of 0.6 and 0.3 exhibited a high concentration of strong basic sites and, as a consequence, showed higher catalytic activity than the $\mathrm{H}-\mathrm{ZrCe} 1.2$ catalyst. The obtained results revealed that the guarantee of low carbon deposition was due to the presence of $\mathrm{Zr}$ species in the lattice of periclase-like mixed oxides, which besides influencing basicity, also result in the formation of small Ni crystallites, inactive in direct methane decomposition and the Boudouard reaction [113].

Unlike Ce and $\mathrm{Zr}$, La as a promoter can not only improve the anti-coke ability, but also enhance catalytic performance [104]. Side reactions such as methane decomposition were promoted at the same time; however, La can form oxycarbonate species and promote gasification of amorphous carbon deposits, resulting in lower carbon formation during the long-duration isothermal experiments performed at $550{ }^{\circ} \mathrm{C}$. La-NiMgAl-LDO catalyst with 2 wt \% La showed a 33\% $\mathrm{CH}_{4}$ conversion at $550{ }^{\circ} \mathrm{C}$, slightly higher than that of the un-promoted NiMgAl-LDO catalyst.

\subsubsection{The Types of Carbon Deposition}

Carbon deposition is unavoidable during DRM and lead to catalyst deactivation. Different carbon species are formed according to the composition of catalysts and the reaction temperature. Thus, many researchers investigated the types of carbon formed on the catalysts' surface. The main types of carbon were amorphous carbon, graphite, carbon nanotubes (CNTs) and carbon nanofibers (CNFs).

Amorphous carbon reflected no impediment to the DRM reaction [84], while encapsulated carbon was mainly responsible for nickel-containing catalysts' deactivation, because the nickel crystallites were encapsulated by the carbon structures. Simultaneously, Daza et al. [94] also showed that different types of carbon formed at different temperatures. At $750{ }^{\circ} \mathrm{C}$, carbon nanotubes (CNTs) and carbon nanofibers (CNFs) were formed, and the filamentous carbons were well-crystallized, yet displayed many structural defects, which increased the resistivity to fracture and prevented the encapsulation of active sites; while at 700 and $650{ }^{\circ} \mathrm{C}$, carbon species were mainly graphite ribbons, coated carbon, nanoencapsulated graphite and $\mathrm{Ni}$ particles embedded inside the carbon were mainly responsible for the catalysts' deactivation. Such types of carbon are deeply sensitive to reaction temperature. Düdder et al. [114] found that CNFs formed at $800^{\circ} \mathrm{C}$, and the formation was suppressed at $900{ }^{\circ} \mathrm{C}$, whereas graphitic carbon formed at $900^{\circ} \mathrm{C}$; thus, $\mathrm{CNFs}$ are the most deactivating carbon species.

Plenty of works have been done on the application of LDH-derived catalysts to dry reforming of methane, and various LDH-derived catalysts have been developed. Dry reforming of methane was considered as the ideal type of reforming process, the main challenge being catalysts' sintering, carbon deposition and applications to industrial applications. As "super-dry" reforming of methane has been developed, this process obtained higher purity $\mathrm{H}_{2}$, suppressed side reactions and coke deposition, saved energy compared with traditional dry reforming of methane and was promising for industrial application. Catalytic performance of dry reforming of $\mathrm{CH}_{4}$ for different catalysts in different works were summarized in Table 3. 
Table 3. Catalytic performance of dry reforming of $\mathrm{CH}_{4}$ for different catalysts in different works.

\begin{tabular}{|c|c|c|c|c|c|c|}
\hline Catalyst & $\mathrm{Ni}(w \mathrm{t} \%)$ & $\begin{array}{c}\mathrm{T} \\
\left({ }^{\circ} \mathrm{C}\right)\end{array}$ & $\begin{array}{c}\text { GHSV } \\
\left(\mathrm{mL} \mathrm{g}^{-1} \mathrm{~h}^{-1}\right)\end{array}$ & $\begin{array}{c}\mathrm{CO}_{2} / \mathrm{CH}_{4} \\
\text { Ratios }\end{array}$ & $\begin{array}{c}\mathrm{CH}_{4} \\
\text { Conversion (\%) }\end{array}$ & Ref. \\
\hline $\mathrm{Ru} / \mathrm{Mg}_{3}(\mathrm{Al}) \mathrm{O}$ & 2 & 800 & 60,000 & 1 & 84 & [71] \\
\hline NiMgAl-700 & 10 & 800 & 8000 & 1 & 95 & [79] \\
\hline $\mathrm{Mg}_{5} \mathrm{NiAl}_{2} \mathrm{O}_{9}$ & 20 & 850 & $7200 \mathrm{~h}^{-1}$ & 1.25 & 95.8 & {$[72]$} \\
\hline $\mathrm{NiMgAl}-\mathrm{LDO} / \gamma-\mathrm{Al}_{2} \mathrm{O}_{3}$ & 9.6 & 700 & 24,000 & 1 & 80.7 & [83] \\
\hline $\mathrm{NiO}-\mathrm{MgO}-\mathrm{Al}_{2} \mathrm{O}_{3}$ & 13.47 & 800 & 5000 & $1.0 / 1.1$ & 91 & [82] \\
\hline $\mathrm{Ru} / \mathrm{Co}_{\mathrm{x}} \mathrm{Mg}_{\mathrm{y}} \mathrm{Al}_{2}$ & - & 750 & - & 1 & 97 & [105] \\
\hline spc-Ni/Mg-Al & 25.1 & 800 & 54,000 & 1 & 94.5 & [81] \\
\hline $\mathrm{Ni} / \mathrm{CeO}_{2}-\mathrm{ZrO}_{2} / \mathrm{MgAl}_{2} \mathrm{O}_{4}$ & 15 & 850 & 5000 & 0.4 & 81 & [115] \\
\hline $\mathrm{La}-\mathrm{NiMgAlO}$ & 2.8 & 750 & 48,000 & 1 & 90 & [91] \\
\hline $\mathrm{CeO}_{2}-\mathrm{Ni} / \mathrm{MgAl}_{2} \mathrm{O}_{4}$ & 12 & 850 & 5000 & 0.4 & 86.2 & [116] \\
\hline $\mathrm{Ni} / \mathrm{Mg} / \mathrm{Al} / \mathrm{Ce}$ & 48.03 & 700 & 48,000 & 1 & 80 & [92] \\
\hline $\mathrm{Ce}-\mathrm{Ni} / \mathrm{Mg}-\mathrm{Al}$ & $50 \mathrm{~mol} \%$ & 700 & 48,000 & 92.3 & 89.4 & [94] \\
\hline $\mathrm{Ce}-\mathrm{Ni} / \mathrm{Mg} / \mathrm{Al}$ & $50 \mathrm{~mol} \%$ & 800 & 30,000 & 100 & 95 & [97] \\
\hline HS-550 & $10(\mathrm{NiO})$ & 800 & 12,000 & 1 & $85 \%$ & [101] \\
\hline HT-NiAl & 63.5 & 550 & $20,000 h^{-1}$ & 2 & 48 & [108] \\
\hline HT-100Ni & 58.66 & 550 & $20,000 \mathrm{~h}^{-1}$ & 1 & 55 & [110] \\
\hline $\mathrm{H}-18 \mathrm{NiCe}$ & 17.9 & 550 & $20,000 \mathrm{~h}^{-1}$ & 1 & 41 & [111] \\
\hline HTNi-CeZr & 19.3 & 550 & $20,000 \mathrm{~h}^{-1}$ & 1 & 25 & [112] \\
\hline NiLaMgAl & 15 & 550 & $20,000 h^{-1}$ & 1 & 33 & [103] \\
\hline HT-NiMgA & 5 & 750 & - & 1 & 87.5 & [98] \\
\hline IR-NiMgAl-LDH@m-SiO 2 & 5.84 & 800 & - & 1 & 90 & [99] \\
\hline $\mathrm{Co}_{2} \mathrm{Mg}_{4} \mathrm{Al}_{2} \mathrm{HT} 500$ & $25 \mathrm{~mol} \%$ & 800 & - & 1 & 96 & [104] \\
\hline Ni-Mg-Al-nano-spheroid & 15 & 800 & - & 1 & 95 & [100] \\
\hline $12 \% \mathrm{Co} / \mathrm{Mg}_{3} \mathrm{Al}$ & 12 & 800 & 60,000 & 1 & 90 & [103] \\
\hline R-C-350-1.8-800 & 10 & 800 & 48,000 & 1 & 80 & [33] \\
\hline 1Co-2Ni-LDH & 5 & 800 & 30,000 & $4 / 6$ & 98.3 & [106] \\
\hline
\end{tabular}

\subsection{Steam Reforming of Methane}

Steam reforming of $\mathrm{CH}_{4}$ is the most common and generally the most economic way to produce $\mathrm{H}_{2}$. During the steam reforming of methane (MSR) process, there are two main reactions: steam reforming of methane (MSR) and the water gas shift reaction (WGS) [8,9]:

$$
\begin{gathered}
\mathrm{CH}_{4}+\mathrm{H}_{2} \mathrm{O} \leftrightarrow \mathrm{CO}+3 \mathrm{H}_{2} \Delta \mathrm{H}=206 \mathrm{~kJ} / \mathrm{mol} \\
\mathrm{CO}+\mathrm{H}_{2} \mathrm{O} \leftrightarrow \mathrm{CO}_{2}+\mathrm{H}_{2} \Delta \mathrm{H}=-41 \mathrm{~kJ} / \mathrm{mol}
\end{gathered}
$$

Because of the endothermicity of the reaction, conventional catalysts have the disadvantage of easy carbon deposition, though a high steam to carbon (S/C) ratio can be used to inhibit carbon formation, and the production costs is high. LDHs like catalysts show higher anti-coke and anti-sintering ability than conventional alumina-supported catalysts (Figure 8) [72,117].

$\mathrm{Ni} / \mathrm{Al}$ LDH-derived catalyst was used as the MSR catalyst. Comas et al. [118] noticed that both reactants $\mathrm{CH}_{4}$ and $\mathrm{H}_{2} \mathrm{O}$ competed for the same active site of $\mathrm{Ni}$ during the SMR reaction, and $\mathrm{CH}_{4}$ conversion presented a maximum or decreased when the water feed concentration increased. When $20 \mathrm{mg}$ of catalyst were used, the $\mathrm{CH}_{4}$ conversion reached a maximum of $46 \%$ at $\mathrm{H}_{2} \mathrm{O} / \mathrm{CH}_{4}=4$. Nickel-supported LDHs displayed higher resistance to coke formation than the conventional $\mathrm{Ni} / \gamma-\mathrm{Al}_{2} \mathrm{O}_{3}$ and $\mathrm{Ni} / \mathrm{CaO}-\mathrm{Al}_{2} \mathrm{O}_{3}$ catalysts, due to smaller $\mathrm{Ni}$ crystals showing a larger saturation concentration level of filamentous carbon than larger Ni crystals, which lead to the smaller driving force for carbon diffusion [117]. Ni-based LDH-derived catalyst composed by the co-precipitation route exhibited stronger metal-support interaction than that prepared by the incipient wetness method and gave smaller Ni crystals [119]. Catalyst prepared by co-precipitation exhibited high activity and excellent stability: for the $40 \mathrm{Ni} / \mathrm{HT}$ catalyst with $40 \mathrm{wt} \% \mathrm{Ni}$ and $\mathrm{Ni}$ dispersion this was $10.8 \%$, showing a $56 \% \mathrm{CH}_{4}$ conversion and no obvious decrease after $25 \mathrm{~h}$ of reaction at $650{ }^{\circ} \mathrm{C}$, much higher than that of commercial catalyst, which displayed $1.5 \% \mathrm{Ni}$ dispersion was and $10 \% \mathrm{CH}_{4}$ conversion. Dehghan-Niri et al. [120] reported that the spatially confined Ni nanoparticle inside a cage of porous 
ribbons had a relatively long distance between themselves, providing significant anti-sintering ability, which brought about a much lower deactivation rate than the commercial Ni catalyst.

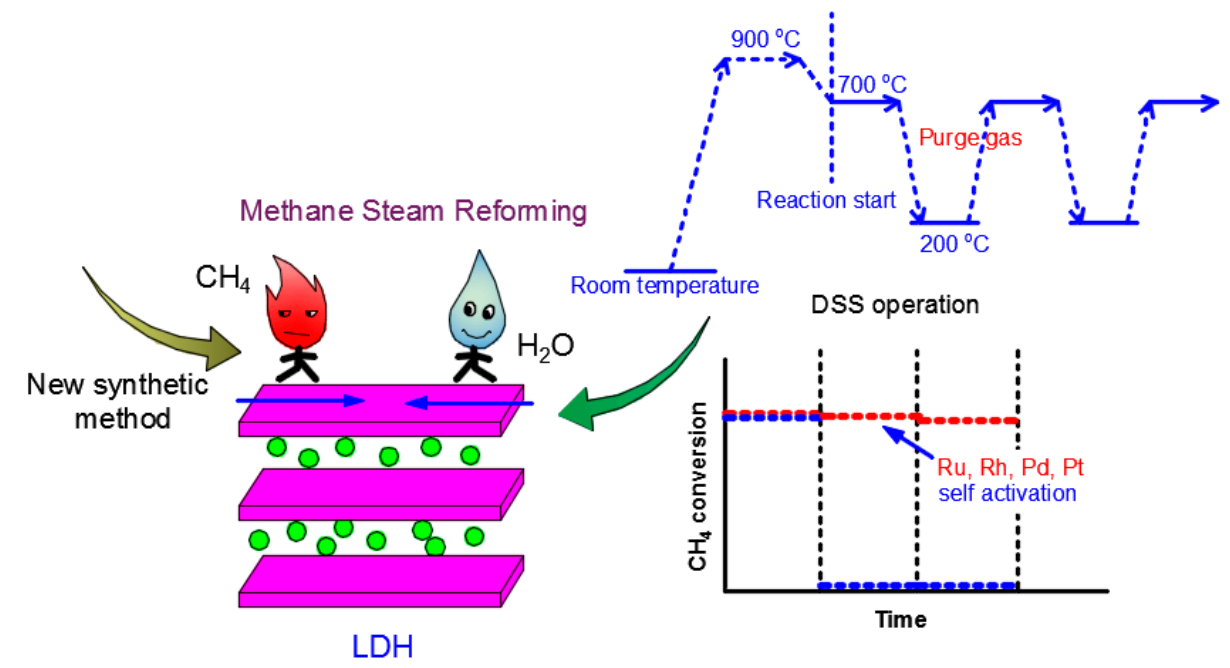

Figure 8. The application of LDHs in steam reforming of methane.

Solid phase crystallization (spc) was also a valuable route to prepare highly efficient and eminent catalyst compared with the incipient wetness method [121]. The as-prepared $\mathrm{spc}-\mathrm{Ni}_{0.5} / \mathrm{Mg}_{2.5}-\mathrm{Al}$ catalyst formed $\mathrm{NiO}-\mathrm{MgO}$ solid solution during the thermal treatment, resulting in well-dispersed $\mathrm{Ni}$ metal particles on the catalyst. The spc-Ni/Mg-Al catalyst achieved a $60 \% \mathrm{CH}_{4}$ conversion, and no decline in the activity was observed after $560 \mathrm{~h}$.

In addition, electrodeposition was a new and an eminent method in LDH-derived catalyst preparation. Basile et al. [122] introduced and developed a Ni/Al- $\mathrm{NO}_{3} \mathrm{LDH}$-derived catalyst through electrodeposition in a single step on FeCr-alloy foams. Furthermore, the catalytic performance was greatly affected by the deposition time. The exHT-1.2-1000 (ex: after calcination) catalyst prepared under $1000 \mathrm{~s}$ and $-1.2 \mathrm{~V}$ showed the best catalytic performance. However, the maximum $\mathrm{CH}_{4}$ conversion reached the equilibrium value of $67 \%$, due to small and uniform particles of LDHs being deposited on the surface. An eggshell-type $\mathrm{Ni} / \mathrm{Mg}-\mathrm{Al}$ catalyst prepared by replacing a part of the $\mathrm{Mg}^{2+}$ by $\mathrm{Ni}^{2+}$ using the "memory effect" of LDHs' structure showed an enhanced catalytic performance compared with impregnated catalyst [123]. The same catalyst formed "worm-like" structures and eventually constituted a dense $\mathrm{Ni}^{2+}$ layer and covered the surface of the particles, leading to enrichment of active $\mathrm{Ni}$ species. S-spc- $\mathrm{Ni}_{0.51} / \mathrm{Mg}_{2.63} \mathrm{Al}$ (eggshell-type $\mathrm{Ni}$ loaded catalysts) catalyst exhibited the best catalytic performance and achieved a $98.1 \% \mathrm{CH}_{4}$ conversion at $800{ }^{\circ} \mathrm{C}$, with a GHSV $=1.8 \times 10^{5} \mathrm{~mL} \mathrm{~h}^{-1} \mathrm{~g}^{-1}$. Takeguchi et al. [124] analyzed the coke formation of a nickel-based $\mathrm{LDH}$-derived catalyst during steam reforming of methane. The coke deposition rate of the nickel-based $\mathrm{LDH}$-derived catalyst was one third compared with the $\mathrm{Ni} / \mathrm{Al}_{2} \mathrm{O}_{3}$ catalyst because $\mathrm{Ni}$ can be oxidized to a Ni-incorporated LDH structure by water-vapor treatment, and the deposited coke was easily removed by the reaction with oxygen in Ni-incorporated LDH [125].

Besides $\mathrm{Ni}, \mathrm{Ru}, \mathrm{Cu}$ and $\mathrm{Co}$ were also used as active components. The $1 \mathrm{wt} \% \mathrm{Ru}$ supported by $\mathrm{Co}_{6} \mathrm{Al}_{2}$ oxide achieved an $\sim 92 \% \mathrm{CH}_{4}$ conversion at $600{ }^{\circ} \mathrm{C}$, due to the reducible ruthenium and cobalt oxide species at the surface of the support with $\mathrm{Ru}$ adulteration [126]. When the reaction temperature reached to $700{ }^{\circ} \mathrm{C}$, the catalyst displayed $100 \% \mathrm{CH}_{4}$ conversion. $\mathrm{Cu}$ as an active component showed slightly lower catalytic performance than $\mathrm{Ru}$, but also was an effective active ingredient. Moreover, Homsi et al. [8] studied the influence of copper content on the catalytic performance. The $5 \mathrm{Cu} / \mathrm{Co}_{6} \mathrm{Al}_{2}$ catalyst with $5 \mathrm{wt} \% \mathrm{Cu}$ showed the best catalytic performance and achieved a $96 \%$ methane conversion at $650{ }^{\circ} \mathrm{C}$. With the increasing copper content, the catalyst activity decreased due to the formation of agglomerated and less reactive $\mathrm{CuO}$ species. The $5 \mathrm{Cu} / \mathrm{Co}_{6} \mathrm{Al}_{2}$ catalyst can also achieve $100 \%$ 
methane conversion when the reaction temperature reached $700{ }^{\circ} \mathrm{C}$. Lucr'edio et al. [127] used Co as the active component and studied the influence of the preparation method on the catalytic performance. Catalysts prepared by the traditional technique (traditional co-precipitation method; cobalt nitrate used as the Co ion source) and the anion-exchange method showed good activity, maintaining around $80 \%$ conversions during $6 \mathrm{~h}$ of reaction. While catalyst prepared by the co-precipitation method (cobalt complex chelate used as the Co ion source) showed an initial fall in conversion, it then remained around $40 \%$, which was caused by cobalt active sites' partial oxidation.

When catalyst is extensively used at the industry scale and operated at daily startup and shutdown (DSS) conditions, the catalyst bed must be purged by a sufficiently inert and an economically viable gas to prevent Ni metal from being oxidized, which could lead to deactivation [128]. Nonetheless, Ohi et al. [129] probed three kinds of purge gas and found that air as the purge gas led to quick deactivation of the oxidized surface metal Ni; spent gas was the most inert for the DSS operation and caused no significant deactivation; as the most convenient purge gas has a great relation to the $(\mathrm{Mg}+\mathrm{Ni}) / \mathrm{Al}$ ratio in $\mathrm{Ni} / \mathrm{Mg}(\mathrm{Al}) \mathrm{O}$ catalysts, the most stable operation was achieved with a ratio of $6 / 1$, while the $(\mathrm{Mg}+\mathrm{Ni}) / \mathrm{Al}$ ratio of 3/1 being the most prolific for the steady state operation validated the evident deactivation due to $\mathrm{Mg}(\mathrm{Al}) \mathrm{O}$ being hydrated by steam to form $\mathrm{Mg}(\mathrm{OH})_{2}$, resulting in the oxidation of $\mathrm{Ni}$ metal. $\mathrm{Ni}_{0.5} / \mathrm{Mg}_{2.5}(\mathrm{Al}) \mathrm{O}$ catalyst achieved a $91 \% \mathrm{CH}_{4}$ initial conversion, sharply decreasing to $45 \%$ under the first shut down, with deactivation after four cycles of the DSS operation [130]. However, when $\mathrm{Ru}$ was introduced to $\mathrm{Ni}_{0.5} / \mathrm{Mg}_{2.5}(\mathrm{Al}) \mathrm{O}$, the catalytic performance was effectively preserved under DSS operating conditions. Ru was introduced to the "memory effect" and formed Ru-Ni alloy, which had a strong interaction and effectively suppressed the deactivation. Besides, only $0.05 \mathrm{wt} \%$ of Ru loading was enough to suppress the deactivation effectively during the DSS-like operation. In follow-up work [131-133], the author researched the effect of other noble metals such as Rh, Pd and Pt in DSS operating conditions. In addition, Pd was not effective enough compared with $\mathrm{Rh}$ addition, since deactivation can be observed. Nevertheless, $\mathrm{Rh}$ and $\mathrm{Pt}$ with a loading of $0.05 \mathrm{wt} \%$ were effective at enhancing the stability of $\mathrm{Ni}_{0.5} / \mathrm{Mg}_{2.5}(\mathrm{Al}) \mathrm{O}$ catalyst. The enhancement of stability under DSS operating conditions of $\mathrm{Ru}, \mathrm{Pt}$ and $\mathrm{Rh}$ can be attributed to self-activation of the noble metal-Ni bimetal catalyst: the noble metal rather kept the reduced state during the steam purging and dissociated $\mathrm{CH}_{4}$ to form hydrogen atoms after the temperature reached $700{ }^{\circ} \mathrm{C}$, then hydrogen atoms migrated to the oxidized Ni species by spillover and reduced them to the active Ni metals.

In conclusion, more research should be performed on the LDH-derived catalyst, for it holds promise as catalysts or supports of the SRM catalyst. Since SRM was the most common way to produce $\mathrm{H}_{2}$, more high-efficiency catalyst that show excellent catalytic performance and anti-coke ability should be explored. Moreover, reaction mechanism also can be researched to help design higher efficiency catalyst. Catalytic performance of steam reforming of $\mathrm{CH} 4$ for different catalysts in different works were summarized in Table 4.

Table 4. Catalytic performance of steam reforming of $\mathrm{CH}_{4}$ for different catalysts in different works.

\begin{tabular}{|c|c|c|c|c|c|c|c|}
\hline Catalyst & Ni (wt \%) & $\begin{array}{c}\mathrm{T} \\
\left({ }^{\circ} \mathrm{C}\right)\end{array}$ & $\begin{array}{c}\text { Pressure } \\
(\mathrm{MPa})\end{array}$ & $\begin{array}{c}\text { GHSV } \\
\left(\mathrm{mL} \mathrm{h}^{-1} \mathrm{~g}^{-1}\right)\end{array}$ & $\begin{array}{c}\text { S/C } \\
\text { Ratios }\end{array}$ & $\begin{array}{c}\mathrm{CH}_{4} \\
\text { Conversion (\%) }\end{array}$ & Ref. \\
\hline $40 \mathrm{Ni} / \mathrm{HT}$ & 40 & 650 & 0.1 & - & 3 & 56 & [119] \\
\hline spc-Ni0.5/Mg2.5-Al & $\sim 9.8$ & 740 & 0.1 & 2890 & 1.6 & 60 & [134] \\
\hline exHT-1.2-1000 & 1.2 & 900 & 2 & - & 1.7 & 67 & [122] \\
\hline s-spc $\mathrm{Ni}_{0.51} / \mathrm{Mg}_{2.63}$ & 8.2 & 800 & - & 180,000 & 2 & 98.1 & [123] \\
\hline $\mathrm{Ru} / \mathrm{Co}_{6} \mathrm{Al}_{2}$ & $1(\mathrm{Ru})$ & 700 & 0.1 & - & 3 & 100 & [126] \\
\hline $5 \mathrm{Cu} / \mathrm{Co}_{6} \mathrm{Al}_{2}$ & $5(\mathrm{Cu})$ & 700 & 0.1 & 15,000 & 3 & 100 & [9] \\
\hline Ae-MgAl-CoY & $12.5 \mathrm{~mol} \%(\mathrm{Co})$ & 750 & - & $49 \mathrm{~h}^{-1}$ & 2 & 80 & [127] \\
\hline
\end{tabular}




\subsection{Partial Oxidation of Methane}

Catalytic partial oxidation of methane (POM), a mild exothermic process operated at short contact times, offered the greatest potential to synthesis of gas or hydrogen [10]. POM has become the focus of researches due to its obvious advantages, such as mild exothermicity, high energy efficiency and suitable $\mathrm{CO} / \mathrm{H}_{2}$ ratio for methanol synthesis, and could be conducted in small reactors ideal for decentralized applications $[11,12]$. The equation is as follows:

$$
\mathrm{CH}_{4}+1 / 2 \mathrm{O}_{2} \rightarrow \mathrm{CO}+2 \mathrm{H}_{2} \Delta \mathrm{H}=-35.5 \mathrm{~kJ} / \mathrm{mol}
$$

LDH-derived catalysts are also suitable catalysts for the POM reaction, as shown in Figure 9. Rh-based catalysts are very active in the POM, and Basile et al. [135-138] explored Rh containing $\mathrm{LDH}$-derived $\mathrm{Rh} / \mathrm{Mg} / \mathrm{Al}$ catalysts, which showed better catalytic performance compared with supported $\mathrm{Rh} / \mathrm{A}_{2} \mathrm{O}_{3}$. $\mathrm{Rh} / \mathrm{Mg} / \mathrm{Al}$ catalysts with a metal ratio of 5.0/71.0/24.0 achieved $91 \% \mathrm{CH}_{4}$ conversion at $750{ }^{\circ} \mathrm{C}$. Rh-based LDH-derived catalysts also have been electro-synthesized on a FeCrAlY foam through the cathodic reduction of a solution containing metal salts and $\mathrm{KNO}_{3}$, the best catalytic performance being achieved by the catalyst obtained from the HT precursor prepared at $-1.3 \mathrm{~V}$ for $1000 \mathrm{~s}$. The coating of as-obtained catalyst RhexHT-1.3 $\mathrm{pH}$ has a high adhesion to the surface, exhibiting the best catalytic performance with a $90 \% \mathrm{CH}_{4}$ conversion at $750{ }^{\circ} \mathrm{C}$.

Even though Rh catalysts were very active in the POM of methane, the reduced availability and high cost of Rh could make it unsuitable for widespread commercial applications. Ru was less expensive than $\mathrm{Rh}$ and was active in the conversion of $\mathrm{CH}_{4}$. Ballarini et al. [139] unveiled the role of the composition and preparation method in the activity of LDH-derived Ru catalysts in the catalytic partial oxidation of methane. Both $\mathrm{Ru}$ dispersion and the interaction with the support decreased as the $\mathrm{Ru}$ loading increased and when silicates were present due to $\mathrm{RuO}_{2}$ segregation, and the 0.25 wt $\% \mathrm{Ru} / \mathrm{Mg} / \mathrm{Al}-\mathrm{CO}_{3}$ catalyst exhibited the best performance due to an enhanced metal-support interaction, carbon resistance and thermal stability. The $0.25 \mathrm{wt} \% \mathrm{Ru} / \mathrm{Mg} / \mathrm{Al}-\mathrm{CO}_{3}$ catalyst achieved $92 \% \mathrm{CH}_{4}$ conversion and almost $100 \% \mathrm{CO}$ selectivity at $750{ }^{\circ} \mathrm{C}$ with a volume ratio of $\mathrm{CH}_{4} / \mathrm{O}_{2} / \mathrm{He}=2 / 1 / 20$. Simultaneously, Velasco et al. [140] also found that with $\mathrm{Ru}$ addition, the catalyst showed excellent carbon resistance ability compared to the monometallic nickel catalysts. Harada et al. [141] used $\mathrm{Ba}_{1.0} \mathrm{Co}_{0.7} \mathrm{Fe}_{0.2} \mathrm{Nb}_{3-\delta}$ (BCFN) dense ceramic supported by $\mathrm{Mg}$-Al compound as an oxygen-permeable membrane for partial oxidation of methane; in $300 \mathrm{~h}$, the oxygen permeation flux BCFN remained greater than $20 \mathrm{~mL} /\left(\mathrm{cm}^{2} \mathrm{~min}\right)$. With the combination of the oxygen-permeable membrane, $\mathrm{Ru} 2 \mathrm{wt} \% / \mathrm{MgAlO}_{\mathrm{x}}$ catalyst afforded the best oxygen permeation performance and achieved initial methane conversion of $85 \%$. This was the first report of such a high flux performance for a reaction in $300 \mathrm{~h}$.

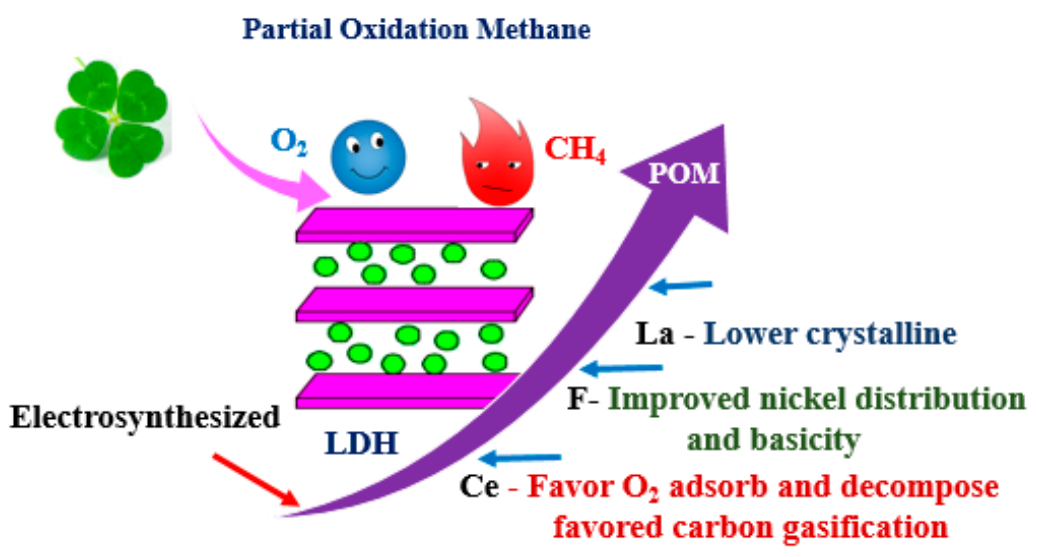

Figure 9. The application of LDHs in partial oxidation of methane. POM, partial oxidation of methane. 
Catalysts with lower $\mathrm{Ni}$ content activated after a severe reduction treatment can show high stability during the reaction, while catalysts with high $\mathrm{Ni}$ content required mild reduction conditions and deactivated rapidly with time-on-stream due to carbon formation. The synergetic effect of Rh and $\mathrm{Ni}$ in $\mathrm{Rh} / \mathrm{Ni} \mathrm{LDH}$-derived catalysts can increase the reducibility of Ni due to Rh being able to catalyze methane reacted with oxygen and increasing the surface temperature at the beginning of the bed [137].

$\mathrm{La}_{2} \mathrm{O}_{3}$ had a beneficial effect on the nickel dispersion, and the catalysts promoted with lanthanum toward $\mathrm{CO}_{2}$ reforming methane presented good conversion levels and lower carbon formation than unprompted catalysts. Thus, it was also a potential promoter of the POM reaction. Zhang et al. [10] found that the addition of La lowered the phase crystallization with the formation of small oxide particles. The as-prepared $\mathrm{Ni} / \mathrm{Mg} / \mathrm{Al} / \mathrm{La}$ mixed oxides had both high activities and stabilities, the catalyst containing $6.5 \mathrm{~mol} \%$ La showing the highest performance at $800{ }^{\circ} \mathrm{C}$ with a $\mathrm{CH}_{4}$ conversion of $99 \%$, a CO selectivity of $93 \%$ and a $\mathrm{H}_{2}$ selectivity of $96 \%$, which could be attributed to the presence of highly dispersed nickel and then the resistance to coke formation due to the promotion effect of lanthanum. Besides lanthanum, another rare-earth metal, cerium, also can increase the CO selectivity and decrease the carbon formation rate. With the cerium addition, oxygen was favorable to adsorbtion and decomposition with respect to these promoted catalysts, which favored the gasification of carbon species [142]. La- and Ce-promoted catalyst showed slightly lower catalytic performance, but achieved a higher $\mathrm{CO}$ selectivity than the un-promoted catalyst. The reason for higher selectivity was that La and $\mathrm{Ce}$ increased the surface basicity with consequent carbon reduction, which favored the dissociative adsorption of the oxygen in these catalysts [142].

Transition metals and rare-earth metals as promoters have been widely studied; non-metallic elements as the promoter have also displayed a positive effect. Zhang et al. [20] successfully introduced $\mathrm{F}$ into Ni-Mg-Al mixed oxide via the high dispersion of $\mathrm{MgF}_{2}$, which led to the formation of the periclase-type catalyst with a mesoporous structure. Fluorine-modified catalyst showed a low surface area and small Ni particle size, but high-moderate and strong basicity and exhibited excellent catalytic performance for POM without deactivation even after a 120 -h run at $800{ }^{\circ} \mathrm{C}$. The high catalytic performance resulted from $\mathrm{F}^{-}$anions improving the homogeneous distribution of nickel and the basicity of the catalyst with high resistance to coking and sintering. $\mathrm{Ni} / \mathrm{Mg} / \mathrm{AlO}-\mathrm{F}$ catalyst achieved almost $100 \% \mathrm{CH}_{4}$ conversion at $800{ }^{\circ} \mathrm{C}$.

Cobalt has also been used as the active component in the POM reaction. Choudhary and Mamman found that at a molar ratio of $\mathrm{CH}_{4}: \mathrm{O}_{2}=4: 1$, the $\mathrm{CoO}-\mathrm{MgO}$ and $\mathrm{NiO}-\mathrm{MgO}$ catalysts presented similar results at $700{ }^{\circ} \mathrm{C}$ [143]. Additionally, Lucre'dio et al. [142] utilized CoMgAl-Ht as the catalyst for the POM reaction, and the as-prepared catalyst displayed about $50 \% \mathrm{CH}_{4}$ conversion at $750{ }^{\circ} \mathrm{C}$, which reached equilibrium. From existing research, $\mathrm{LDH}$-derived catalysts were propitious for POM. Even though POM required a lower amount of thermal energy compared with DRM and SRM, it required pure oxygen, which may lead to a danger with two combustible reagents. Catalytic performance of steam reforming of $\mathrm{CH}_{4}$ for different catalysts in different works were summarized in Table 5.

Table 5. Catalytic performance of partial oxidation of $\mathrm{CH}_{4}$ for different catalysts in different works.

\begin{tabular}{|c|c|c|c|c|c|c|c|}
\hline Catalyst & $\mathrm{Ni}(w \mathrm{t} \%)$ & $\begin{array}{c}\mathrm{T} \\
\left({ }^{\circ} \mathrm{C}\right)\end{array}$ & $\begin{array}{l}\text { Pressure } \\
\text { (MPa) }\end{array}$ & $\begin{array}{l}\text { GHSV } \\
\left(h^{-1}\right)\end{array}$ & $\begin{array}{c}\mathrm{CH}_{4} / \mathrm{O}_{2} \\
\text { Ratios }\end{array}$ & $\begin{array}{c}\mathrm{CH}_{4} \\
\text { Conversion (\%) }\end{array}$ & Ref. \\
\hline RhexHT-1.3pH & $0.2(\mathrm{Rh})$ & 750 & 0.1 & 28,000 & 2 & 90 & [140] \\
\hline $\mathrm{Ni} / \mathrm{Mg} / \mathrm{Al} / \mathrm{La}$ & 21 & 800 & - & - & 2 & 99 & [11] \\
\hline $\mathrm{Ru} / \mathrm{Mg} / \mathrm{AleCO}_{3}$ & $0.25(\mathrm{Ru})$ & 750 & - & - & 2 & 92 & [141] \\
\hline CoMgAl-Ht & $5 \mathrm{~mol} \%(\mathrm{Co})$ & 750 & 0.1 & - & 2 & 50 & [142] \\
\hline $\mathrm{Ni} / \mathrm{Mg} / \mathrm{AlO}-\mathrm{F}$ & $36 \mathrm{~mol} \mathrm{\%}$ & 800 & 0.1 & - & 2 & 100 & [26] \\
\hline
\end{tabular}

\subsection{Autothermal Reforming}

Autothermal reforming (ATR) is the combination of SMR and POM reactions, and the general reaction for ATR is described in Equation (12) [144]: 


$$
\mathrm{CH} 4+\frac{1}{2} \mathrm{xO}_{2}+\mathrm{yCO}_{2}+(1-\mathrm{x}-\mathrm{y}) \mathrm{H}_{2} \mathrm{O} \leftrightarrow(\mathrm{y}+1) \mathrm{CO}+(3-\mathrm{x}-\mathrm{y}) \mathrm{H}_{2}
$$

It has low-energy requirements due to the opposite contribution of the exothermic methane oxidation and endothermic steam reforming; thus, it can avoid the necessity of a large external supply of heat and the cost of oxygen/nitrogen separation [13]. The combination of these two reactions can improve the reactor temperature, control and reduce the formation of hot spots and avoid catalyst deactivation by sintering or carbon deposition. Moreover, the $\mathrm{H}_{2} / \mathrm{CO}$ ratio of syngas produced by ATR has a wider range through manipulating the relative concentrations of $\mathrm{H}_{2} \mathrm{O}$ and $\mathrm{O}_{2}$ in the feed [14,15].

$\mathrm{Ni}$ - and/or Rh-containing LDHs have been used as catalysts for autothermal reforming of methane (in the presence or absence of ethane). NiRh alloy particles were formed in $\mathrm{NiRh} / \mathrm{MgAl}$, which was enriched in $\mathrm{Ni}$ [13]. $\mathrm{NiRh} / \mathrm{MgAl}$ catalyst hardly catalyzed coke formation during $\mathrm{CH}_{4}$ autothermal reforming and exhibited excellent stability due to $\mathrm{H}_{2}$ spillover from $\mathrm{Rh}$ in the $\mathrm{NiRh}$ alloy against $\mathrm{Ni}$ oxidation. $\mathrm{NiRh} / \mathrm{MgAl}$ catalyst displayed a $93 \% \mathrm{CH}_{4}$ conversion at $500{ }^{\circ} \mathrm{C}$ [13]. Luneau et al. [144] tested the long-term stability of a series of catalysts in a six parallel-flow reactor and found that the $5-0.05 \mathrm{wt} \% \mathrm{Ni}-\mathrm{Rh} / \mathrm{MgAl}_{2} \mathrm{O}_{4}$ catalyst was robust for the autothermal reforming of model biogas, because Rh can effectively promote nickel reduction and prevent bulk oxidation. Likewise, Souza et al. [145] researched Ni-Mg-Al LDH-derived catalysts with varied Ni content for $\mathrm{CH}_{4}$ autothermal reforming. All catalysts exhibited only $\mathrm{MgO}$-periclase phase X-ray diffraction peaks, suggesting that both nickel and aluminum were well dispersed in the $\mathrm{MgO}$ matrix. The performance of LDH-derived catalysts was very similar, with a $\mathrm{CH}_{4}$ conversion of about $85 \%$, without any apparent deactivation during the stability test at $800{ }^{\circ} \mathrm{C}$. All catalysts achieved a maximum $\mathrm{CH}_{4}$ conversion of $94 \%$ at $900{ }^{\circ} \mathrm{C}$.

Besides the co-precipitation method, the solid-phase crystallization method (spc) was an effective method to prepare high efficiency catalysts and has been used to prepare catalysts for the DRM and SRM reaction. The spc- $\mathrm{Ni}_{0.5} / \mathrm{Mg}_{2.5} \mathrm{Al}$ catalyst with a ratio of $\mathrm{Mg} / \mathrm{Al}$ of $1 / 3$ showed excellent autothermal reforming performance [146]. Meanwhile, Ni dispersion was further enhanced during the spc preparation process. The spc- $\mathrm{Ni}_{0.5} / \mathrm{Mg}_{2.5} \mathrm{Al}$ catalyst attained almost a $97.5 \% \mathrm{CH}_{4}$ conversion at $800{ }^{\circ} \mathrm{C}$ and showed no deactivation during the 50-h stability test. In order to obtain high purity $\mathrm{H}_{2}$, $\mathrm{LDH}$-derived catalyst also used $\mathrm{CO}_{2}$ as the sorbent in sorption-enhanced autothermal reforming of methane. Combined with a traditional $\mathrm{Ni} / \mathrm{MgO}$ catalyst, $\mathrm{CH}_{4}$ conversion was enhanced to $99.5 \%$ with a $\mathrm{H}_{2}$ purity of $99.5 \%$, higher than that without $\mathrm{LDH}$-derived $\mathrm{CO}_{2}$ sorbent: $85 \%$ and $96 \%$, respectively $[147,148]$.

Autothermal reforming (ATR) was energy saving, and the $\mathrm{H}_{2} / \mathrm{CO}$ ratio ranges between one and two [7]. Thus, autothermal reforming was also a good choice to produce syngas. Since LDH-derived catalysts displayed excellent catalytic performance and $\mathrm{LDH}$-derived $\mathrm{CO}_{2}$ sorbent applied to sorption-enhanced autothermal reforming can produce higher purity $\mathrm{H}_{2}$, thus more attention should be paid to this research, and new efficient catalysts should be further explored. Catalytic performance of autothermal reforming for different catalysts in different works were summarized in Table 6.

Table 6. Catalytic performance of autothermal reforming for different catalysts in different works.

\begin{tabular}{|c|c|c|c|c|c|c|c|}
\hline Catalyst & $\begin{array}{c}\mathrm{Ni} \\
(w \mathrm{t} \%)\end{array}$ & $\begin{array}{c}\mathrm{T} \\
\left({ }^{\circ} \mathrm{C}\right)\end{array}$ & $\begin{array}{l}\text { Pressure } \\
\text { (MPa) }\end{array}$ & $\begin{array}{c}\text { GHSV } \\
\left(\mathrm{mL} \mathrm{g}^{-1} \mathrm{~h}^{-1}\right)\end{array}$ & $\begin{array}{c}\mathrm{CH}_{4} / \mathrm{O}_{2} / \mathrm{H}_{2} \mathrm{O} \\
\text { Ratios }\end{array}$ & $\underset{\text { Conversion (\%) }}{\mathrm{CH}_{4}}$ & Ref. \\
\hline $\mathrm{NiRh} / \mathrm{MgAl}$ & 25 & 500 & - & $1,700,000$ & $2 / 1 / 2$ & 93 & [13] \\
\hline $10 \mathrm{NiHT}$ & 10 & 900 & 0.1 & $160 \mathrm{~h}^{-1}$ & $4 / 1 / 2$ & 94 & [145] \\
\hline spc- $\mathrm{Ni}_{0.5} / \mathrm{Mg}_{2.5} \mathrm{Al}$ & 16.3 & 800 & - & 150,000 & $2 / 1 / 2$ & $\sim 97.5$ & [146] \\
\hline
\end{tabular}

\section{Conclusions}

As conventional 2D materials, LDHs showed small crystal sizes, high surface area, compositional flexibility, memory effect and basic properties, and the as-obtained catalysts displayed large surface area, high thermal stability and a high extent of dispersion of metallic particles after reduction, 
so being considered as suitable supports or catalysts for $\mathrm{CO} / \mathrm{CO}_{2}$ methanation and the methane reforming reaction.

(1) Methanation

The NiAl-LDH catalyst with a high Ni loading showed good catalytic performance, but poor anti-sintering ability. The introduction of dopants can effectively decrease the Ni content, improve the reducibility and enhance the interaction between nickel and LDH-based supports, thus further improving the catalytic performance and anti-sintering ability. However, the research of LDH-derived catalysts in the methanation reaction was inadequate. As promising catalysts for the methanation reaction, much further work will be necessary, especially for the single-layer LDHs. The atomic monolayers benefit from the high-speed transfer of the carrier in the material, show similar wrinkles as for graphene and favor the dispersion of the active component as monodispersed nanoparticles, which have great potential in single-atom catalysts.

(2) Methane reforming

Similar to the methanation reaction, the NiAl-LDH catalyst has been also used for the methane reforming reaction, and plenty of work has been performed to restrain the coke deposition. Dopants ( $\mathrm{Rh}, \mathrm{La}, \mathrm{Ce}, \mathrm{C}$, etc.) can improve the anti-coke ability of catalysts by improving the active dispersion, enhancing the interaction between the active component and the support and increasing the surface basic sites. Different synthesis methods have also been studied. Besides, the morphology also evidently influences the anti-coke ability, and the monolithic and egg-shell catalysts have shown better anti-coke ability in the dry-reforming reaction. They are also promising catalysts in other kinds of methane reforming.

In addition, the "memory effect" synthesis scheme is also a favorable method for the preparation of highly dispersed LDH-derived catalysts for both methanation and methane reforming reactions. So far, although some dopants have been introduced, the diversification of LDH-derived catalysts is not sufficient, and multicomponent LDH-derived catalysts should be explored.

Acknowledgments: This work was financially supported by the National Natural Science Foundation of China (No. U1203293, 51572029, 51622801), the Program for Changjiang Scholars, Innovative Research Team in University (No. IRT_15R46), and the Program of Science and Technology Innovation Team in Bingtuan (No. 2015BD003).

Conflicts of Interest: The authors declare no conflict of interest.

\section{References}

1. Liu, H.; He, D. Recent progress on Ni-based catalysts in partial oxidation of methane to syngas. Catal. Surv. Asia 2012, 16, 53-61. [CrossRef]

2. Shan, J.; Li, M.; Allard, L.F.; Lee, S.; Flytzani-Stephanopoulos, M. Mild oxidation of methane to methanol or acetic acid on supported isolated rhodium catalysts. Nature 2017, 551, 605-608. [CrossRef] [PubMed]

3. Craciun, R.; Daniell, W.; Knözinger, $\mathrm{H}$. The effect of $\mathrm{CeO}_{2}$ structure on the activity of supported pd catalysts used for methane steam reforming. Appl. Catal. A Gen. 2002, 230, 153-168. [CrossRef]

4. Wei, J.M.; Xu, B.Q.; Li, J.L.; Cheng, Z.X.; Zhu, Q.M. Highly active and stable $\mathrm{Ni} / \mathrm{ZrO}_{2}$ catalyst for syngas production by $\mathrm{CO}_{2}$ reforming of methane. Appl. Catal. A Gen. 2000, 196, L167-L172. [CrossRef]

5. Elmasides, C.; Verykios, X.E. Mechanistic study of partial oxidation of methane to synthesis gas over modified $\mathrm{Ru} / \mathrm{TiO}_{2}$ catalyst. J. Catal. 2001, 203, 477-486. [CrossRef]

6. Zhang, Z.J.; Wang, Q.; Zhu, Y.Q.; Chen, X.Y. Nanoporous graphitic carbon materials: Systematic incorporation of $\mathrm{p}-/ \mathrm{m}$-/o-nitroaniline as effective redox additives for largely improving the capacitive performance. Carbon 2016, 100, 564-577. [CrossRef]

7. Neiva, A.; Gama, A. A study on the characteristics of the reforming of methane: A review. Braz. J. Pet. Gas 2010, 4, 119-127. [CrossRef]

8. Micheli, F.; Sciarra, M.; Courson, C.; Gallucci, K. Catalytic steam methane reforming enhanced by $\mathrm{CO}_{2}$ capture on $\mathrm{CaO}$ based bi-functional compounds. J. Energy Chem. 2017, 26, 1014-1025. [CrossRef] 
9. Homsi, D.; Aouad, S.; Gennequin, C.; Nakat, J.E.; Aboukaïs, A.; Abi-Aad, E. The effect of copper content on the reactivity of $\mathrm{Cu} / \mathrm{Co}_{6} \mathrm{Al}_{2}$ solids in the catalytic steam reforming of methane reaction. Comptes Rendus Chim. 2014, 17, 454-458. [CrossRef]

10. Enger, B.C.; Lødeng, R.; Holmen, A. A review of catalytic partial oxidation of methane to synthesis gas with emphasis on reaction mechanisms over transition metal catalysts. Appl. Catal. A Gen. 2008, 346, 1-27. [CrossRef]

11. Zhang, J.; Zhao, N.; Wei, W.; Sun, Y. Partial oxidation of methane over Ni/Mg/Al/La mixed oxides prepared from layered double hydrotalcites. Int. J. Hydrogen Energy 2010, 35, 11776-11786. [CrossRef]

12. Freni, S.; Calogero, G.; Cavallaro, S. Hydrogen production from methane through catalytic partial oxidation reactions. J. Power Source 2000, 87, 28-38. [CrossRef]

13. Nagaoka, K.; Jentys, A.; Lercher, J.A. Methane autothermal reforming with and without ethane over monoand bimetal catalysts prepared from hydrotalcite precursors. J. Catal. 2005, 229, 185-196. [CrossRef]

14. Liu, S.; Xiong, G.; Dong, H.; Yang, W. Effect of carbon dioxide on the reaction performance of partial oxidation of methane over a $\mathrm{LiLaNiO} / \gamma-\mathrm{Al}_{2} \mathrm{O}_{3}$ catalyst. Appl. Catal. A Gen. 2000, 202, 141-146. [CrossRef]

15. Liu, Z.W.; Jun, K.W.; Roh, H.S.; Park, S.E. Hydrogen production for fuel cells through methane reforming at low temperatures. J. Power Source 2002, 111, 283-287. [CrossRef]

16. Liu, Q.; Gao, J.; Gu, F.; Lu, X.; Liu, Y.; Li, H.; Zhong, Z.; Liu, B.; Xu, G.; Su, F. One-pot synthesis of ordered mesoporous $\mathrm{Ni}-\mathrm{V}-\mathrm{Al}$ catalysts for CO methanation. J. Catal. 2015, 326, 127-138. [CrossRef]

17. Kok, E.; Scott, J.; Cant, N.; Trimm, D. The impact of ruthenium, lanthanum and activation conditions on the methanation activity of alumina-supported cobalt catalysts. Catal. Today 2011, 164, 297-301. [CrossRef]

18. Soltanieh, M.; Azar, K.M.; Saber, M. Development of a zero emission integrated system for co-production of electricity and methanol through renewable hydrogen and $\mathrm{CO}_{2}$ capture. Int. J. Greenh. Gas Control 2012, 7 , 145-152. [CrossRef]

19. Metiu, H. $\mathrm{CO}_{2}$ methanation on Ru-doped ceria. J. Catal. 2011, 278, 297-309.

20. Zhu, X.; Shi, Y.; Cai, N. $\mathrm{CO}_{2}$ residual concentration of potassium-promoted hydrotalcite for deep $\mathrm{CO} / \mathrm{CO}_{2}$ purification in $\mathrm{H}_{2}$-rich gas. J. Energy Chem. 2017, 26, 956-964. [CrossRef]

21. Cruz-Hernández, A.; Mendoza-Nieto, J.A.; Pfeiffer, H. NiO-CaO materials as promising catalysts for hydrogen production through carbon dioxide capture and subsequent dry methane reforming. J. Energy Chem. 2017, 26, 942-947. [CrossRef]

22. Gao, W.; Zhou, T.; Gao, Y.; Louis, B.; O’Hare, D.; Wang, Q. Molten salts-modified MgO-based adsorbents for intermediate-temperature $\mathrm{CO}_{2}$ capture: A review. J. Energy Chem. 2017, 26, 830-838. [CrossRef]

23. Zhang, Z.; Wang, J.; Huang, L.; Gao, Y.; Umar, A.; Huang, Z.; Wang, Q. The influence of synthesis method on the $\mathrm{CO}_{2}$ adsorption capacity of $\mathrm{Mg}_{3} \mathrm{Al}-\mathrm{CO}_{3}$ hydrotalcite-derived adsorbents. Sci. Adv. Mater. 2014, 6, 1154-1159. [CrossRef]

24. Wang, Q.; Gao, Y.; Zhang, Z.; Duan, L.; Umar, A.; O’Hare, D. Synthesis and characterization of high surface area flower-like ca-containing layered double hydroxides Mg3-xCaxAl1-NO3. Sci. Adv. Mater. 2013, 5, 411-420. [CrossRef]

25. Xu, Y.; Cheng, C.; Du, S.; Yang, J.; Yu, B.; Luo, J.; Yin, W.; Li, E.; Dong, S.; Ye, P. Contacts between twoand three-dimensional materials: Ohmic, schottky, and p-n heterojunctions. ACS Nano 2016, 10, 4895-4919. [CrossRef] [PubMed]

26. Zhang, J.; Wei, W.; Sun, Y. Fluorine-modified mesoporous Ni-Mg-Al mixed oxides for partial oxidation of methane. Catal. Lett. 2010, 135, 321-329. [CrossRef]

27. Dumitriu, E.; Hulea, V.; Chelaru, C.; Catrinescu, C.; Tichit, D.; Durand, R. Influence of the acid-base properties of solid catalysts derived from hydrotalcite-like compounds on the condensation of formaldehyde and acetaldehyde. Appl. Catal. A Gen. 1999, 178, 145-157. [CrossRef]

28. Liu, K.; Xu, Y.; Yao, Z.; Miras, H.N.; Song, Y.F. Polyoxometalate-intercalated layered double hydroxides as efficient and recyclable bifunctional catalysts for cascade reactions. ChemCatChem 2016, 8, 929-937. [CrossRef]

29. Yao, Z.; Miras, H.N.; Song, Y.F. Efficient concurrent removal of sulfur and nitrogen contents from complex oil mixtures by using polyoxometalate-based composite materials. Inorg. Chem. Front. 2016, 3, 1007-1013. [CrossRef]

30. Han, J.; Dou, Y.; Wei, M.; Evans, D.G.; Duan, X. Erasable nanoporous antireflection coatings based on the reconstruction effect of layered double hydroxides. Angew. Chem. 2010, 49, 2171-2174. [CrossRef] [PubMed] 
31. Takehira, K. Recent development of layered double hydroxide-derived catalysts—rehydration, reconstitution, and supporting, aiming at commercial application-. Appl. Clay Sci. 2017, 136, 112-141. [CrossRef]

32. Cavani, F.; Trifirò, F.; Vaccari, A. Hydrotalcite-type anionic clays: Preparation, properties and applications. Catal. Today 1991, 11, 173-301. [CrossRef]

33. Jin, L.; Xie, T.; Ma, B.; Li, Y.; Hu, H. Preparation of carbon-Ni/MgO- $\mathrm{Al}_{2} \mathrm{O}_{3}$ composite catalysts for $\mathrm{CO}_{2}$ reforming of methane. Int. J. Hydrogen Energy 2017, 42, 5047-5055. [CrossRef]

34. Li, P.; Zhu, M.; Tian, Z.; Han, Y.; Zhang, Y.; Zhou, T.; Kang, L.; Dan, J.; Guo, X.; Yu, F.; et al. Two-dimensional layered double hydroxide derived from vermiculite waste water supported highly dispersed ni nanoparticles for co methanation. Catalysts 2017, 7, 79. [CrossRef]

35. Bian, L.; Wang, W.; Xia, R.; Li, Z. Ni-based catalyst derived from Ni/Al hydrotalcite-like compounds by the urea hydrolysis method for CO methanation. RSC Adv. 2015, 6, 677-686. [CrossRef]

36. Habazaki, H.; Yamasaki, M.; Zhang, B.P.; Kawashima, A.; Kohno, S.; Takai, T.; Hashimoto, K. Co-methanation of carbon monoxide and carbon dioxide on supported nickel and cobalt catalysts prepared from amorphous alloys. Appl. Catal. A Gen. 1998, 172, 131-140. [CrossRef]

37. Zhang, M.; Li, P.; Zhu, M.; Tian, Z.; Dan, J.; Li, J.; Dai, B.; Yu, F. Ultralow-weight loading Ni catalyst supported on two-dimensional vermiculite for carbon monoxide methanation. Chin. J. Chem. Eng. 2017, in press. [CrossRef]

38. Dai, B.; Wen, B.; Zhu, M.; Kang, L.; Yu, F. Nickel catalysts supported on amino-functionalized MCM-41 for syngas methanation. RSC Adv. 2016, 6, 66957-66962. [CrossRef]

39. Li, P.; Zhu, M.; Dan, J.; Kang, L.; Lai, L.; Cai, X.; Zhang, J.; Yu, F.; Tian, Z.; Dai, B. Two-dimensional porous $\mathrm{SiO}_{2}$ nanomesh supported high dispersed ni nanoparticles for $\mathrm{CO}$ methanation. Chem. Eng. J. 2017, 326, 774-780. [CrossRef]

40. Al-Fatish, A.; Ibrahim, A.; Fakeeha, A.; Soliman, M.; Siddiqui, M.; Abasaeed, A. Coke formation during $\mathrm{CO}_{2}$ reforming of $\mathrm{CH}_{4}$ over alumina-supported nickel catalysts. Appl. Catal. A Gen. 2009, 364, 150-155. [CrossRef]

41. Rostrup-Nielsen, J.R.; Pedersen, K.; Sehested, J. High temperature methanation: Sintering and structure sensitivity. Appl. Catal. A Gen. 2007, 330, 134-138. [CrossRef]

42. Mohaideen, K.K.; Kim, W.; Koo, K.Y.; Wang, L.Y. Highly dispersed Ni particle on Ru/NiAl catalyst derived from layered double hydroxide for selective CO methanation. Catal. Commun. 2014, 60, 8-13. [CrossRef]

43. Rathouský, J.; Schulz-Ekloff, G.; Stárek, J.; Zukal, A. Supported nickel catalyst from hydroxycarbonate of nickel and aluminium. Chem. Eng. Technol. 1994, 17, 41-46. [CrossRef]

44. Kelley, R.D.; Candela, G.A.; Madey, T.E.; Newbury, D.E.; Schehl, R.R. Surface and bulk analysis of a deactivated raney nickel methanation catalyst. J. Catal. 1983, 80, 235-248. [CrossRef]

45. Betta, R.A.D.; Piken, A.G.; Shelef, M. Heterogeneous methanation: Steady-state rate of CO hydrogenation on supported ruthenium, nickel and rhenium. J. Catal. 1975, 40, 173-183.

46. Hwang, S.; Lee, J.; Hong, U.G.; Ji, C.J.; Dong, J.K.; Lim, H.; Byun, C.; Song, I.K. Hydrogenation of carbon monoxide to methane over mesoporous nickel-m-alumina $(\mathrm{m}=\mathrm{Fe}, \mathrm{Ni}, \mathrm{Co}, \mathrm{Ce}$, and $\mathrm{La})$ xerogel catalysts. J. Ind. Eng. Chem. 2012, 18, 243-248. [CrossRef]

47. Kustov, A.L.; Frey, A.M.; Larsen, K.E.; Johannessen, T.; Nørskov, J.K.; Christensen, C.H. Co methanation over supported bimetallic Ni-Fe catalysts: From computational studies towards catalyst optimization. Appl. Catal. A Gen. 2007, 320, 98-104. [CrossRef]

48. Li, Z.; Bian, L.; Zhu, Q.; Wang, W. Ni-based catalyst derived from Ni/Mg/Al hydrotalcite-like compounds and its activity in the methanation of carbon monoxide. Kinet. Catal. 2014, 55, 217-223. [CrossRef]

49. Collet, P.; Flottes, E.; Favre, A.; Raynal, L.; Pierre, H.; Capela, S.; Peregrina, C. Techno-economic and life cycle assessment of methane production via biogas upgrading and power to gas technology. Appl. Energy 2017, 192, 282-295. [CrossRef]

50. Abate, S.; Barbera, K.; Giglio, E.; Deorsola, F.; Bensaid, S.; Perathoner, S.; Pirone, R.; Centi, G. Synthesis, characterization, and activity pattern of $\mathrm{Ni}-\mathrm{Al}$ hydrotalcite catalysts in $\mathrm{CO}_{2}$ methanation. Ind. Eng. Chem. Res. 2016, 55, 8299-8308. [CrossRef]

51. Gabrovska, M.; Edreva-Kardjieva, R.; Crişan, D.; Tzvetkov, P.; Shopska, M.; Shtereva, I. Ni-Al layered double hydroxides as catalyst precursors for $\mathrm{CO}_{2}$ removal by methanation. React. Kinet. Mech. Catal. 2012, 105, 79-99. [CrossRef]

52. Rahmani, S.; Rezaei, M.; Meshkani, F. Preparation of promoted nickel catalysts supported on mesoporous nanocrystalline gamma alumina for carbon dioxide methanation reaction. J. Ind. Eng. Chem. 2014, 20, 4176-4182. [CrossRef] 
53. Westermann, A.; Azambre, B.; Bacariza, M.C.; Graça, I.; Ribeiro, M.F.; Lopes, J.M.; Henriques, C. The promoting effect of ce in the $\mathrm{CO}_{2}$ methanation performances on niusy zeolite: A ftir in situ/operando study. Catal. Today 2017, 283, 74-81. [CrossRef]

54. Tada, S.; Shimizu, T.; Kameyama, H.; Haneda, T.; Kikuchi, R. Ni/CeO 2 catalysts with high $\mathrm{CO}_{2}$ methanation activity and high $\mathrm{CH}_{4}$ selectivity at low temperatures. Int. J. Hydrogen Energy 2012, 37, 5527-5531. [CrossRef]

55. Hwang, S.; Hong, U.G.; Lee, J.; Seo, J.G.; Baik, J.H.; Dong, J.K.; Lim, H.; Song, I.K. Methanation of carbon dioxide over mesoporous $\mathrm{Ni}-\mathrm{Fe}-\mathrm{Al}_{2} \mathrm{O}_{3}$ catalysts prepared by a coprecipitation method: Effect of precipitation agent. J. Ind. Eng. Chem. 2013, 19, 2016-2021. [CrossRef]

56. Bette, N.; Thielemann, J.; Schreiner, M.; Mertens, F. Methanation of $\mathrm{CO}_{2}$ over a (Mg,Al)Ox supported nickel catalyst derived from a (Ni,Mg,Al)-hydrotalcite-like precursor. Chem CatChem 2016, 8, 2903-2906. [CrossRef]

57. Fan, M.T.; Miao, K.P.; Lin, J.D.; Zhang, H.B.; Liao, D.W. Mg-Al oxide supported Ni catalysts with enhanced stability for efficient synthetic natural gas from syngas. Appl. Surf. Sci. 2014, 307, 682-688. [CrossRef]

58. Wierzbicki, D.; Motak, M.; Grzybek, T.; Gálvez, M.E.; Costa, P.D. The influence of lanthanum incorporation method on the performance of nickel-containing hydrotalcite-derived catalysts in $\mathrm{CO}_{2}$ methanation reaction. Catal. Today 2017, in press. [CrossRef]

59. Wierzbicki, D.; Debek, R.; Motak, M.; Grzybek, T.; Gálvez, M.E.; Costa, P.D. Novel Ni-La-hydrotalcite derived catalysts for $\mathrm{CO}_{2}$ methanation. Catal. Commun. 2016, 83, 5-8. [CrossRef]

60. Nizio, M.; Benrabbah, R.; Krzak, M.; Debek, R.; Motak, M.; Cavadias, S.; Gálvez, M.E.; Costa, P.D. Low temperature hybrid plasma-catalytic methanation over Ni-Ce-Zr hydrotalcite-derived catalysts. Catal. Commun. 2016, 83, 14-17. [CrossRef]

61. Xu, Y.; Chen, Y.; Li, J.; Zhou, J.; Song, M.; Zhang, X.; Yin, Y. Improved low-temperature activity of $\mathrm{Ni}-\mathrm{Ce} / \gamma-\mathrm{Al}_{2} \mathrm{O}_{3}$ catalyst with layer structural precursor prepared by cold plasma for $\mathrm{CO}_{2}$ methanation. Int. J. Hydrogen Energy 2017, 42, 13085-13091. [CrossRef]

62. Sun, Y.; Cheng, H.; Gao, S.; Sun, Z.; Liu, Q.; Liu, Q.; Lei, F.; Yao, T.; He, J.; Wei, S. Freestanding tin disulfide single-layers realizing efficient visible-light water splitting. Angew. Chem. Int. Ed. 2012, 51, 8727-8731. [CrossRef] [PubMed]

63. Li, H.; Tran, T.N.; Lee, B.J.; Zhang, C.; Park, J.D.; Kang, T.H.; Yu, J.S. Synthesis of water-dispersible single-layer coal-carbonate layered double hydroxide. ACS Appl. Mater. Interfaces 2017, 9, 20294-20298. [CrossRef] [PubMed]

64. Ren, J.; Ouyang, S.; Xu, H.; Meng, X.; Wang, T.; Wang, D.; Ye, J. Photothermal catalysis: Targeting activation of $\mathrm{CO}_{2}$ and $\mathrm{H}_{2}$ over Ru-loaded ultrathin layered double hydroxides to achieve efficient photothermal $\mathrm{CO}_{2}$ methanation in flow-type system. Adv. Energy Mater. 2017, 7. [CrossRef]

65. Mark, M.F.; Maier, W.F. $\mathrm{CO}_{2}$-reforming of methane on supported Rh and Ir catalysts. J. Catal. 1996, 164, 122-130. [CrossRef]

66. Erdohelyi, A.; Cserenyi, J.; Solymosi, F. Activation of $\mathrm{CH}_{4}$ and its reaction with $\mathrm{CO}_{2}$ over supported Rh catalysts. J. Catal. 1993, 141, 287-299. [CrossRef]

67. Kroll, V.C.H.; Swaan, H.M.; Lacombe, S.; Mirodatos, C. Methane reforming reaction with carbon dioxide over $\mathrm{Ni} / \mathrm{SiO}_{2}$ catalyst: Ii. A mechanistic study. J. Catal. 1996, 164, 387-398. [CrossRef]

68. Richardson, J.T.; Paripatyadar, S.A. Carbon dioxide reforming of methane with supported rhodium. Appl. Catal. 1990, 61, 293-309. [CrossRef]

69. Solymosi, F.; Kutsán, G.; Erdöhelyi, A. Catalytic reaction of $\mathrm{CH}_{4}$ with $\mathrm{CO}_{2}$ over alumina-supported Pt metals. Catal. Lett. 1991, 11, 149-156. [CrossRef]

70. Qin, D.; Lapszewicz, J. Study of mixed steam and $\mathrm{CO}_{2}$ reforming of $\mathrm{CH}_{4}$ to syngas on mgo-supported metals. Catal. Today 1994, 21, 551-560. [CrossRef]

71. Li, D.; Li, R.; Lu, M.; Lin, X.; Zhan, Y.; Jiang, L. Carbon dioxide reforming of methane over Ru catalysts supported on $\mathrm{Mg}$-Al oxides: A highly dispersed and stable $\mathrm{Ru} / \mathrm{Mg}(\mathrm{Al}) \mathrm{O}$ catalyst. Appl. Catal. B Environ. 2017, 200, 566-577. [CrossRef]

72. Bhattacharyya, A.; Chang, V.W.; Schumacher, D.J. $\mathrm{CO}_{2}$ reforming of methane to syngas: I: Evaluation of hydrotalcite clay-derived catalysts. Appl. Clay Sci. 1998, 13, 317-328. [CrossRef]

73. Touahra, F.; Sehailia, M.; Ketir, W.; Bachari, K.; Chebout, R.; Trari, M.; Cherifi, O.; Halliche, D. Effect of the $\mathrm{Ni} / \mathrm{Al}$ ratio of hydrotalcite-type catalysts on their performance in the methane dry reforming process. Appl. Petrochem. Res. 2016, 6, 1-13. [CrossRef] 
74. Mette, K.; Kühl, S.; Düdder, H.; Kähler, K.; Tarasov, A.; Muhler, M.; Behrens, M. Stable performance of Ni catalysts in the dry reforming of methane at high temperatures for the efficient conversion of $\mathrm{CO}_{2}$ into syngas. ChemCatChem 2014, 6, 100-104. [CrossRef]

75. Mette, K.; Kühl, S.; Tarasov, A.; Düdder, H.; Kähler, K.; Muhler, M.; Schlögl, R.; Behrens, M. Redox dynamics of ni catalysts in $\mathrm{CO}_{2}$ reforming of methane. Catal. Today 2015, 242, 101-110. [CrossRef]

76. Mette, K.; Kühl, S.; Tarasov, A.; Willinger, M.G.; Kröhnert, J.; Wrabetz, S.; Trunschke, A.; Scherzer, M.; Girgsdies, F.; Düdder, H. High-temperature stable Ni nanoparticles for the dry reforming of methane. ACS Catal. 2016, 6, 7238-7248. [CrossRef]

77. Perez-Lopez, O.W.; Senger, A.; Marcilio, N.R.; Lansarin, M.A. Effect of composition and thermal pretreatment on properties of $\mathrm{Ni}-\mathrm{Mg}-\mathrm{Al}$ catalysts for $\mathrm{CO}_{2}$ reforming of methane. Appl. Catal. A Gen. 2006, 303, 234-244. [CrossRef]

78. Zhu, Y.; Zhang, S.; Chen, B.; Zhang, Z.; Shi, C. Effect of Mg/Al ratio of nimgal mixed oxide catalyst derived from hydrotalcite for carbon dioxide reforming of methane. Catal. Today 2016, 264, 163-170. [CrossRef]

79. Li, N.; Shen, C.; Tan, P.; Zuo, Z.; Huang, W. Effect of phase transformation on the stability of Ni-Mg-Al catalyst for dry reforming of methane. Indian J. Chem. 2015, 54, 1198-1205.

80. Buelens, L.C.; Galvita, V.V.; Poelman, H.; Detavernier, C.; Marin, G.B. Super-dry reforming of methane intensifies $\mathrm{CO}_{2}$ utilization via le chatelier's principle. Science 2016, 354, 449-452. [CrossRef] [PubMed]

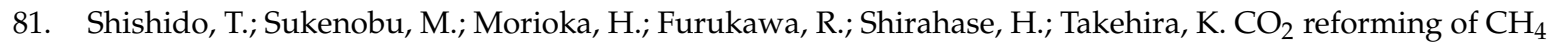
over $\mathrm{Ni} / \mathrm{Mg}-\mathrm{Al}$ oxide catalysts prepared by solid phase crystallization method from $\mathrm{Mg}-\mathrm{Al}$ hydrotalcite-like precursors. Catal. Lett. 2001, 73, 21-26. [CrossRef]

82. Chai, R.; Fan, S.; Zhang, Z.; Chen, P.; Zhao, G.; Liu, Y.; Lu, Y. Free-standing NiO-MgO- $\mathrm{Al}_{2} \mathrm{O}_{3}$ nanosheets derived from layered double hydroxides grown onto fecral-fiber as structured catalysts for dry reforming of methane. ACS Sustain. Chem. Eng. 2017, 5, 4517-4522. [CrossRef]

83. Xu, Z.; Wang, N.; Chu, W.; Deng, J.; Luo, S. In situ controllable assembly of layered-double-hydroxide-based nickel nanocatalysts for carbon dioxide reforming of methane. Catal. Sci. Technol. 2015, 5, 1588-1597. [CrossRef]

84. Zhang, X.; Wang, N.; Xu, Y.; Yin, Y.; Shang, S. A novel Ni-Mg-Al-LDHs $/ \gamma-\mathrm{Al}_{2} \mathrm{O}_{3}$ catalyst prepared by in-situ synthesis method for $\mathrm{CO}_{2}$ reforming of $\mathrm{CH}_{4}$. Catal. Commun. 2014, 45, 11-15. [CrossRef]

85. Lucrédio, A.F.; Assaf, J.M.; Assaf, E.M. Methane conversion reactions on Ni catalysts promoted with Rh: Influence of support. Appl. Catal. A Gen. 2011, 400, 156-165. [CrossRef]

86. Dębek, R.; Motak, M.; Galvez, M.E.; Grzybek, T.; Da Costa, P. Promotion effect of zirconia on Mg (Ni, Al)O mixed oxides derived from hydrotalcites in $\mathrm{CO}_{2}$ methane reforming. Appl. Catal. B: Environ. 2018, 223, 36-46. [CrossRef]

87. Yu, X.; Wang, N.; Chu, W.; Liu, M. Carbon dioxide reforming of methane for syngas production over La-promoted nimgal catalysts derived from hydrotalcites. Chem. Eng. J. 2012, 209, 623-632. [CrossRef]

88. Serrano-Lotina, A.; Martin, A.J.; Folgado, M.A.; Daza, L. Dry reforming of methane to syngas over La-promoted hydrotalcite clay-derived catalysts. Int. J. Hydrogen Energy 2012, 37, 12342-12350. [CrossRef]

89. Serrano-Lotina, A.; Daza, L.; Serrano-Lotina, A.; Daza, L. Highly stable and active catalyst for hydrogen production from biogas. J. Power Source 2013, 238, 81-86. [CrossRef]

90. Serrano-Lotina, A.; Daza, L. Influence of the operating parameters over dry reforming of methane to syngas. Int. J. Hydrogen Energy 2014, 39, 4089-4094. [CrossRef]

91. Serrano-Lotina, A.; Daza, L. Long-term stability test of Ni-based catalyst in carbon dioxide reforming of methane. Appl. Catal. A Gen. 2014, 474, 107-113. [CrossRef]

92. Daza, C.E.; Gallego, J.; Moreno, J.A.; Mondragón, F.; Moreno, S.; Molina, R. $\mathrm{CO}_{2}$ reforming of methane over $\mathrm{Ni} / \mathrm{Mg} / \mathrm{Al} / \mathrm{Ce}$ mixed oxides. Catal. Today 2008, 133, 357-366. [CrossRef]

93. Daza, C.E.; Moreno, S.; Molina, R. Co-precipitated Ni-Mg-Al catalysts containing Ce for CO reforming of methane. Int. J. Hydrogen Energy 2011, 36, 3886-3894. [CrossRef]

94. Daza, C.E.; Gallego, J.; Mondragón, F.; Moreno, S.; Molina, R. High stability of Ce-promoted Ni/Mg-Al catalysts derived from hydrotalcites in dry reforming of methane. Fuel 2010, 89, 592-603. [CrossRef]

95. Djebarri, B.; Gonzalez-Delacruz, V.M.; Halliche, D.; Bachari, K.; Saadi, A.; Caballero, A.; Holgado, J.P.; Cherifi, O. Erratum to: Promoting effect of ce and $\mathrm{Mg}$ cations in $\mathrm{Ni} / \mathrm{Al}$ catalysts prepared from hydrotalcites for the dry reforming of methane. React. Kinet. Mech. Catal. 2014, 111, 817. [CrossRef] 
96. Ren, H.P.; Song, Y.H.; Wang, W.; Chen, J.G.; Cheng, J.; Jiang, J.; Liu, Z.T.; Liu, Z.W.; Hao, Z.; Lu, J. Insights into $\mathrm{CeO}_{2}$-modified $\mathrm{Ni}-\mathrm{Mg}-\mathrm{Al}$ oxides for pressurized carbon dioxide reforming of methane. Chem. Eng. J. 2015, 259, 581-593. [CrossRef]

97. Daza, C.E.; Cabrera, C.R.; Moreno, S.; Molina, R. Syngas production from $\mathrm{CO}_{2}$ reforming of methane using Ce-doped Ni-catalysts obtained from hydrotalcites by reconstruction method. Appl. Catal. A Gen. 2010, 378, 125-133. [CrossRef]

98. Du, X.; Zhang, D.; Shi, L.; Gao, R.; Zhang, J. Coke- and sintering-resistant monolithic catalysts derived from in situ supported hydrotalcite-like films on Al wires for dry reforming of methane. Nanoscale 2013, 5, 2659-2663. [CrossRef] [PubMed]

99. Du, X.; Zhang, D.; Gao, R.; Huang, L.; Shi, L.; Zhang, J. Design of modular catalysts derived from $\mathrm{NiMgAl}-\mathrm{LDH} @ \mathrm{~m}-\mathrm{SiO}_{2}$ with dual confinement effects for dry reforming of methane. Chem. Commun. 2013, 49, 6770-6772. [CrossRef] [PubMed]

100. González, A.R.; Asencios, Y.J.O.; Assaf, E.M.; Assaf, J.M. Dry reforming of methane on Ni-Mg-Al nano-spheroid oxide catalysts prepared by the sol-gel method from hydrotalcite-like precursors. Appl. Surf. Sci. 2013, 280, 876-887. [CrossRef]

101. Zuo, Z.J.; Shen, C.F.; Tan, P.J.; Huang, W. Ni based on dual-support Mg-Al mixed oxides and SBA-15 catalysts for dry reforming of methane. Catal. Commun. 2013, 41, 132-135. [CrossRef]

102. Damyanova, S.; Pawelec, B.; Arishtirova, K.; Fierro, J.L.G. Ni-based catalysts for reforming of methane with $\mathrm{CO}_{2}$. Int. J. Hydrogen Energy 2012, 37, 15966-15975. [CrossRef]

103. Liu, H.; Wierzbicki, D.; Debek, R.; Motak, M.; Grzybek, T.; Costa, P.D.; Gálvez, M.E. La-promoted Ni-hydrotalcite-derived catalysts for dry reforming of methane at low temperatures. Fuel 2016, 182, 8-16. [CrossRef]

104. Gennequin, C.; Safariamin, M.; Siffert, S.; Aboukaïs, A.; Abi-Aad, E. $\mathrm{CO}_{2}$ reforming of $\mathrm{CH}_{4}$ over $\mathrm{Co}-\mathrm{Mg}-\mathrm{Al}$ mixed oxides prepared via hydrotalcite like precursors. Catal. Today 2011, 176, 139-143. [CrossRef]

105. Gennequin, C.; Hany, S.; Tidahy, H.L.; Aouad, S.; Estephane, J.; Aboukaïs, A.; Abi-Aad, E. Influence of the presence of ruthenium on the activity and stability of $\mathrm{Co}-\mathrm{Mg}-\mathrm{Al}$-based catalysts in $\mathrm{CO}_{2}$ reforming of methane for syngas production. Environ. Sci. Pollut. Res. Int. 2016, 23, 22744-22760. [CrossRef] [PubMed]

106. Zhang, X.; Yang, C.; Zhang, Y.; Xu, Y.; Shang, S.; Yin, Y. Ni-Co catalyst derived from layered double hydroxides for dry reforming of methane. Int. J. Hydrogen Energy 2015, 40, 16115-16126. [CrossRef]

107. Tanios, C.; Bsaibes, S.; Gennequin, C.; Labaki, M.; Cazier, F.; Billet, S.; Tidahy, H.L.; Nsouli, B.; Aboukaïs, A.; Abi-Aad, E. Syngas production by the $\mathrm{CO}_{2}$ reforming of $\mathrm{CH}_{4}$ over $\mathrm{Ni}-\mathrm{Co}-\mathrm{Mg}-\mathrm{Al}$ catalysts obtained from hydrotalcite precursors. Int. J. Hydrogen Energy 2017, 42, 12818-12828. [CrossRef]

108. Dbek, R.; Ribeiro, M.F.G.; Fernandes, A.; Motak, M. Ni-Al hydrotalcite-like material as the catalyst precursors for the dry reforming of methane at low temperature. C. R. Chim. 2015, 18, 1205-1210. [CrossRef]

109. Dębek, R.; Zubek, K.; Motak, M.; Costa, P.D.; Grzybek, T. Effect of nickel incorporation into hydrotalcite-based catalyst systems for dry reforming of methane. Res. Chem. Intermed. 2015, 41, 9485-9495. [CrossRef]

110. Dębek, R.; Motak, M.; Duraczyska, D.; Launay, F.; Galvez, M.E.; Grzybek, T.; Costa, P.D. Methane dry reforming over hydrotalcite-derived $\mathrm{Ni}-\mathrm{Mg}-\mathrm{Al}$ mixed oxides: The influence of Ni content on catalytic activity, selectivity and stability. Catal. Sci. Technol. 2016, 6, 6705-6715. [CrossRef]

111. Dębek, R.; Radlik, M.; Motak, M.; Galvez, M.E.; Turek, W.; Costa, P.D.; Grzybek, T. Ni-containing Ce-promoted hydrotalcite derived materials as catalysts for methane reforming with carbon dioxide at low temperature-on the effect of basicity. Catal. Today 2015, 257, 59-65. [CrossRef]

112. Dębek, R.; Galvez, M.E.; Launay, F.; Motak, M.; Grzybek, T.; Costa, P.D. Low temperature dry methane reforming over $\mathrm{Ce}, \mathrm{Zr}$ and $\mathrm{CeZr}$ promoted $\mathrm{Ni}-\mathrm{Mg}-\mathrm{Al}$ hydrotalcite-derived catalysts. Int. J. Hydrogen Energy 2016, 41, 11616-11623. [CrossRef]

113. Dębek, R.; Motak, M.; Galvez, M.E.; Grzybek, T.; Costa, P.D. Influence of Ce/Zr molar ratio on catalytic performance of hydrotalcite-derived catalysts atlow temperature $\mathrm{CO}_{2}$ methane reforming. Int. J. Hydrogen Energy 2017, 42, 23556-23567. [CrossRef]

114. Düdder, H.; Kähler, K.; Krause, B.; Mette, K.; Kühl, S.; Behrens, M.; Scherer, V.; Muhler, M. Correction: The role of carbonaceous deposits in the activity and stability of Ni-based catalysts applied in the dry reforming of methane. Catal. Sci. Technol. 2014, 4, 3317-3328. [CrossRef] 
115. Bae, J.W.; Kim, A.R.; Baek, S.C.; Jun, K.W. The role of CeO-ZrO distribution on the Ni/MgAlO catalyst during the combined steam and Co reforming of methane. React. Kinet. Mech. Catal. 2011, 104, 377-388. [CrossRef]

116. Baek, S.C.; Bae, J.W.; Cheon, J.Y.; Jun, K.W.; Lee, K.Y. Combined steam and carbon dioxide reforming of methane on $\mathrm{Ni} / \mathrm{MgAl}_{2} \mathrm{O}_{4}$ : Effect of $\mathrm{CeO}_{2}$ promoter to catalytic performance. Catal. Lett. 2011, 141, 224-234. [CrossRef]

117. Christensen, K.O.; Chen, D.; Lødeng, R.; Holmen, A. Effect of supports and Ni crystal size on carbon formation and sintering during steam methane reforming. Appl. Catal. A Gen. 2006, 314, 9-22. [CrossRef]

118. Comas, J.; Dieuzeide, M.L.; Baronetti, G.; Laborde, M.; Amadeo, N. Methane steam reforming and ethanol steam reforming using a $\mathrm{Ni}(\mathrm{ii})-\mathrm{Al}(\mathrm{iii})$ catalyst prepared from lamellar double hydroxides. Chem. Eng. J. 2006, 118, 11-15. [CrossRef]

119. Ochoa-Fernández, E.; Lacalle-Vilà, C.; Christensen, K.O.; Walmsley, J.C.; Rønning, M.; Holmen, A.; Chen, D. Ni catalysts for sorption enhanced steam methane reforming. Top. Catal. 2007, 45, 3-8. [CrossRef]

120. Dehghan-Niri, R.; Walmsley, J.C.; Holmen, A.; Midgley, P.A.; Rytter, E.; Dam, A.H.; Hungria, A.B.; Hernandez-Garrido, J.C.; Chen, D. Nanoconfinement of ni clusters towards a high sintering resistance of steam methane reforming catalysts. Catal. Sci. Technol. 2012, 2, 2476-2484. [CrossRef]

121. Takehira, K.; Shishido, T.; Wang, P.; Kosaka, T.; Takaki, K. Steam reforming of $\mathrm{CH}_{4}$ over supported Ni catalysts prepared from a Mg-Al hydrotalcite-like anionic clay. Phys. Chem. Chem. Phys. 2003, 5, 3801-3810. [CrossRef]

122. Basile, F.; Benito, P.; Del, G.P.; Fornasari, G.; Gary, D.; Rosetti, V.; Scavetta, E.; Tonelli, D.; Vaccari, A. Highly conductive Ni steam reforming catalysts prepared by electrodeposition. Chem. Commun. 2008, 0, 2917-2919. [CrossRef] [PubMed]

123. Takehira, K.; Kawabata, T.; Shishido, T.; Murakami, K.; Ohi, T.; Shoro, D.; Honda, M.; Takaki, K. Mechanism of reconstitution of hydrotalcite leading to eggshelltype $\mathrm{Ni}$ loading on $\mathrm{Mg}-\mathrm{Al}$ mixed oxide. J. Catal. 2005, 231, 92-104. [CrossRef]

124. Takeguchi, T.; Watanabe, H.; Murayama, T.; Takahashi, H.; Ueda, W. Quantitative analysis of coke formation during steam reforming of methane on a nickel-hydrotalcite catalyst under practical operation conditions. Chem. Lett. 2013, 42, 124-126. [CrossRef]

125. Takahashi, H.; Takeguchi, T.; Yamamoto, N.; Matsuda, M.; Kobayashi, E.; Ueda, W. Effect of interaction between $\mathrm{Ni}$ and YSZ on coke deposition during steam reforming of methane on Ni/YSZ anode catalysts for an Ir-sofc. J. Mol. Catal. A Chem. 2011, 350, 69-74. [CrossRef]

126. Homsi, D.; Aouad, S.; Gennequin, C.; Aboukaïs, A.; Abi-Aad, E. Hydrogen production by methane steam reforming over ru and cu supported on hydrotalcite precursors. Adv. Mater. Res. 2011, 324, 453-456. [CrossRef]

127. Lucrédio, A.F.; Assaf, E.M. Cobalt catalysts prepared from hydrotalcite precursors and tested in methane steam reforming. J. Power Source 2006, 159, 667-672. [CrossRef]

128. Natesakhawat, S.; Watson, R.B.; Wang, X.; Ozkan, U.S. Deactivation characteristics of lanthanide-promoted sol-gel Ni/ $\mathrm{Al}_{2} \mathrm{O}_{3}$ catalysts in propane steam reforming. J. Catal. 2005, 234, 496-508. [CrossRef]

129. Ohi, T.; Miyata, T.; Li, D.; Shishido, T.; Kawabata, T.; Sano, T.; Takehira, K. Sustainability of Ni loaded Mg-Al mixed oxide catalyst in daily startup and shutdown operations of $\mathrm{CH}_{4}$ steam reforming. Appl. Catal. A Gen. 2006, 308, 194-203. [CrossRef]

130. Takehira, K.; Ohi, T.; Miyata, T.; Shiraga, M.; Sano, T. Steam reforming of $\mathrm{CH}_{4}$ over Ni-Ru catalysts supported on Mg-Al mixed oxide. Top. Catal. 2007, 42-43, 471-474. [CrossRef]

131. Miyata, T.; Li, D.; Shiraga, M.; Shishido, T.; Oumi, Y.; Sano, T.; Takehira, K. Promoting effect of Rh, Pd and $\mathrm{Pt}$ noble metals to the $\mathrm{Ni} / \mathrm{Mg}(\mathrm{Al}) \mathrm{O}$ catalysts for the DSS-like operation in $\mathrm{CH}_{4}$ steam reforming. Appl. Catal. A Gen. 2006, 310, 97-104. [CrossRef]

132. Miyata, T.; Shiraga, M.; Li, D.; Atake, I.; Shishido, T.; Oumi, Y.; Sano, T.; Takehira, K. Promoting effect of Ru on $\mathrm{Ni} / \mathrm{Mg}(\mathrm{Al}) \mathrm{O}$ catalysts in DSS-like operation of $\mathrm{CH}_{4}$ steam reforming. Catal. Commun. 2007, 8, 447-451. [CrossRef]

133. Li, D.; Zhan, Y.; Nishida, K.; Oumi, Y.; Sano, T.; Shishido, T.; Takehira, K. "Green" preparation of "intelligent" pt-doped $\mathrm{Ni} / \mathrm{Mg}(\mathrm{Al}) \mathrm{O}$ catalysts for daily start-up and shut-down $\mathrm{CH}_{4}$ steam reforming. Appl. Catal. A Gen. 2009, 363, 169-179. [CrossRef]

134. Takehira, K. Highly dispersed and stable supported metal catalysts prepared by solid phase crystallization method. Catal. Surv. Asia 2002, 6, 19-32. [CrossRef] 
135. Basile, F.; Basini, L.; Fornasari, G.; Gazzano, M.; Trifiro, F.; Vaccari, A. Cheminform abstract: New hydrotalcite-type anionic clays containing noble metals. Chem. Conmmun. 1996, 21, 2435-2436. [CrossRef]

136. Basile, F.; Basini, L.; Amore, M.D.; Fornasari, G.; Guarinoni, A.; Matteuzzi, D.; Piero, G.D.; Trifirò, F.; Vaccari, $\mathrm{A} . \mathrm{Ni} / \mathrm{Mg} / \mathrm{Al}$ anionic clay derived catalysts for the catalytic partial oxidation of methane : Residence time dependence of the reactivity features. J. Catal. 1998, 173, 247-256. [CrossRef]

137. Basile, F.; Fornasari, G.; Trifirò, F.; Vaccari, A. Rh-Ni synergy in the catalytic partial oxidation of methane: Surface phenomena and catalyst stability. Catal. Today 2002, 77, 215-223. [CrossRef]

138. Basile, F.; Benito, P.; Fornasari, G.; Monti, M.; Scavetta, E.; Tonelli, D.; Vaccari, A. Novel rh-based structured catalysts for the catalytic partial oxidation of methane. Catal. Today 2010, 157, 183-190. [CrossRef]

139. Ballarini, A.; Benito, P.; Fornasari, G.; Scelza, O.; Vaccari, A. Role of the composition and preparation method inthe activity of hydrotalcite-derived $\mathrm{Ru}$ catalysts in the catalytic partial oxidation of methane. Int. J. Hydrogen Energy 2013, 38, 15128-15139. [CrossRef]

140. Velasco, J.A.; Fernandez, C.; Lopez, L.; Cabrera, S.; Boutonnet, M.; Järås, S. Catalytic partial oxidation of methane over nickel and ruthenium based catalysts under low $\mathrm{O}_{2} / \mathrm{CH}_{4}$ ratios and with addition of steam. Fuel 2015, 153, 192-201. [CrossRef]

141. Harada, M.; Domen, K.; Hara, M.; Tatsumi, T. Ba-Co-Fe-Nb-O dense ceramic as an oxygen permeable membrane for partial oxidation of methane to synthesis gas. Chem. Lett. 2006, 35, 1326-1327. [CrossRef]

142. Lucrédio, A.F.; Jerkiewicz, G.; Assaf, E.M. Cobalt catalysts promoted with cerium and lanthanum applied to partial oxidation of methane reactions. Appl. Catal. B Environ. 2008, 84, 106-111. [CrossRef]

143. Choudhary, V.R.; Mamman, A.S. simultaneous oxidative conversion and $\mathrm{CO}_{2}$ or steam reforming of methane to syngas over CoO-NiO-MgO catalyst. Fuel Energy Abstr. 2000, 73, 345-350. [CrossRef]

144. Luneau, M.; Schuurman, Y.; Meunier, F.C.; Mirodatos, C.; Guilhaume, N. High-throughput assessment of catalyst stability during autothermal reforming of model biogas. Catal. Sci. Technol. 2015, 5, 4390-4397. [CrossRef]

145. Souza, M.M.V.M.; Ribeiro, N.F.P.; Neto, O.R.M.; Cruz, I.O.; Schmal, M. Autothermal reforming of methane over nickel catalysts prepared from hydrotalcite-like compounds. Stud. Surf. Sci. Catal. 2007, 167, 451-456.

146. Takehira, K.; Shishido, T.; Wang, P.; Kosaka, T.; Takaki, K. Autothermal reforming of $\mathrm{CH}_{4}$ over supported Ni catalysts prepared from Mg-Al hydrotalcite-like anionic clay. J. Catal. 2004, 221, 43-54. [CrossRef]

147. Halabi, M.H.; Croon, M.H.J.M.D.; Schaaf, J.V.D.; Cobden, P.D.; Schouten, J.C. Reactor modeling of sorption-enhanced autothermal reforming of methane. Part I: Performance study of hydrotalcite and lithium zirconate-based processes. Chem. Eng. J. 2011, 168, 872-882. [CrossRef]

148. Halabi, M.H.; Croon, M.H.J.M.D.; Schaaf, J.V.D.; Cobden, P.D.; Schouten, J.C. Reactor modeling of sorption-enhanced autothermal reforming of methane. Part II: Effect of operational parameters. Chem. Eng. J. 2011, 168, 883-888. [CrossRef]

(C) 2018 by the authors. Licensee MDPI, Basel, Switzerland. This article is an open access article distributed under the terms and conditions of the Creative Commons Attribution (CC BY) license (http://creativecommons.org/licenses/by/4.0/). 